\title{
The Origins and Effects of Corporate Diversity Programs
}

\section{Citation}

Dobbin, Frank and Alexandra Kalev. 2013. The origins and effects of corporate diversity programs. In The Oxford handbook of diversity and work, ed. Quinetta M. Roberson, 253-281. New York: Oxford Univ. Press.

\section{Published Version}

10.1093/oxfordhb/9780199736355.013.0015

\section{Permanent link}

http://nrs.harvard.edu/urn-3:HUL.InstRepos:32970016

\section{Terms of Use}

This article was downloaded from Harvard University's DASH repository, and is made available under the terms and conditions applicable to Other Posted Material, as set forth at http:// nrs.harvard.edu/urn-3:HUL.InstRepos:dash.current.terms-of-use\#LAA

\section{Share Your Story}

The Harvard community has made this article openly available.

Please share how this access benefits you. Submit a story.

Accessibility 


\section{The Oxford Handbook of Diversity and Work}

Area Editors:

Clinical Psychology

David H. Barlow

Cognitive Neuroscience

Kevin N. Ochsner and Stephen M. Kosslyn

Cognitive Psychology

Daniel Reisberg

Counseling Psychology

Elizabeth M. Altmaier and Jo-Ida C. Hansen

Developmental Psychology

Philip David Zelazo

Health Psychology

Howard S. Friedman

History of Psychology

David B. Baker

Methods and Measurement

Todd D. Little

Neuropsychology

Kenneth M. Adams

Organizational Psychology

Steve W. J. Kozlowksi

Personality and Social Psychology

Kay Deaux and Mark Snyder 


\section{Abstract}

Corporations have implemented a wide range of equal opportunity and diversity programs since the 1960s. This chapter reviews studies of the origins of these programs, surveys that assess the popularity of different programs, and research on the effects of programs on the workforce. Human resources managers championed several waves of innovations: corporate equal opportunity policies and recruitment and training programs in the 1960s; bureaucratic hiring and promotion policies and grievance mechanisms in the 1970s; diversity training, networking, and mentoring programs in the 1980s; and work/family and sexual harassment programs in the 1990s and beyond. It was those managers who designed equal opportunity and diversity programs, not lawyers or judges or government bureaucrats, thus corporate take-up of the programs remains very uneven. Statistical analyses of time-series data on the effects of corporate diversity measures reveal several patterns. Initiatives designed to quash managerial bias, through diversity training, diversity performance

evaluations, and bureaucratic rules, have been broadly ineffective. By contrast, innovations designed to engage managers in promoting workforce integration-mentoring programs, diversity taskforces, and full-time diversity staffers - have led to increases in diversity in the most difficult job to integrate; management. The research has clear implications for corporate and public policy.

Key Words: diversity programs, diversity taskforces, mentoring, diversity training, workforce diversity

Diversity management traces its origins to the civil rights movement and the subsequent antidiscrimination measures adopted by President John F. Kennedy and Congress in the 1960s. From their inception federal antidiscrimination laws were mut on how firms should achieve equality of opportunity. The programs firms adopted, from race relations training to sexual harassment grievance procedures to culture audits, were devised not by Congress or by the executive branch, but by personnel experts keen to expand their purview in the firm. From the early 1980s, when the Reagan administration expressed doubts about the continued need for federal regulation of employment discrimination, employers recast their equal opportunity programs as part of the new diversity management initiative. Firms adopted a host of diversity programs designed to promote exchange between different groups and to facilitate career development for people who had long been left out of the tournament. Soon a wide range of government and private groups were describing these programs as ways to improve group relations and prevent discrimination (EEOC, 1998, p. 197; Glass Ceiling Commission, 1995; SHRM, 1999). Today these programs are the main channel through which antidiscrimination legislation is implemented, yet we know surprisingly little about their effects. 
This chapter chronicles the programs that personnel managers promoted under the banners of equal opportunity and diversity management, charts their spread across American firms between the early 1960s and the early years of the new millennium, and reviews extant evidence of their effects on workforce composition. We address two questions: What have firms been doing to promote diversity? What effects have their efforts had?

\section{Origins and outcomes of}

\section{diversity programs}

Antidiscrimination regulations from the early 1960s stimulated corporate America to develop the precursors to today's diversity programs. John F. Kennedy's Executive Order 10925 from 1961 required federal contractors to take "affirmative action to ensure that applicants are employed, and that employees are treated during employment, without regard to their race, creed, color, or national origin" (Executive Order 10925,26 Fed. Reg. 1961). The year after Kennedy's assassination, Lyndon Johnson signed the Civil Rights Act into law, outlawing employment discrimination based on race, creed, color, national origin, and sex, throughout the private sector. In the meantime, Congress had made it illegal to pay men and women different wages for the same work in the Equal Pay Act of 1963 (Boyle, 1973, p. 86; Nelson \& Bridges, 1999).

Lacking hints from Congress on how to comply with laws against employment discrimination, personnel experts crafted programs based on weapons in their professional arsenal. Civil rights law stimulated what Lauren Edelman terms "endogenous" compliance: those being regulated helped to define the terms of compliance (Edelman, 2002 Edelman, Uggen, \& Erlanger, 1999). This happened in part because Congress had decided not to create a independent regulatory agency to set compliance standards (Chen, 2009). Executives saw quickly that the law was a moving target, and many hired full-time equal opportunity experts, or created new departments, to track changes in the law and in judicial interpretation (Meyer \& Scott, 1992) Judges and bureaucrats in local, state, and federa governments played roles in determining which employer-initiated programs would stand. The system of regulation was "porous;" citizens could appeal to various public authorities to interpret and reinterpret laws (Kelly 2003; Lieberman, 2002), shopping for the venue most likely to support their causes, be it the San Francisco city bureaucracy or the Supreme Court. In this context, companies came to rely on personnel professionals to predict which way the judicial wind would blow. Judges in turn came to accept the "best practices" of leading firms as evidence of good faith (Bisom-Rapp, 2001; Edelman et al., 1999; Krawiec, 2003). What personnel made popular gradually became lawful (Dobbin, 2009). Employer programs came to define fair employ ment and discrimination in the American mind, for the workplace is where Americans came face to face with fair employment laws.

The public's legal consciousness, and its ideas about what discrimination and diversity mean, evolved over time as social scientists, politicians, and management experts promoted new understandings of the world of inequality in dialogue with the courts (Dobbin \& Sutton, 1998; Ewick \& Silbey, 1998; Liberman, 2005; Lieberman, 1998; Stryker, forthcoming). Personnel experts promoted one round of diversity innovations after another. In the 1960s, they wrote nondiscrimination policies based on union contract clauses designed to prevent discrimination against union leaders, and developed new recruitment programs and skills and management training systems to bring in more women and minorities and prepare them for advancement. In the 1970s, as the profession more than doubled in size and as the proportion of women rose from a third to nearly a half, personnel experts created formal hiring and promotion systems designed to create a rulebook for personnel decisions, and thereby deny managers the chance to exercise bias.

When the Reagan administration mounted an assault on fair employment regulations, personnel experts argued that the new hiring and promotion practices helped to rationalize "human resources management" and rebranded their efforts under the heading of diversity management. Equal opportitnity experts now argued not that the law required employers to hire and promote women and minori ties, but that the market required it. Firms woule not remain competitive if they could not figure out how to use the talents of all kinds of workers. Soon race relations workshops became diversity training programs, equal opportunity attitude survey. became corporate culture audits, and affirmative action officers became diversity managers. After 1990 the increasingly feminized human resource profession focused on women's issues, pushing for the expansion of work and family programs and anti-harassment programs. In each period, change in corporate practice altered the meaning of fai employment in the American mind. Some changes altered workforce composition as well
To date, there have been few rigorous studies of he efficacy of different diversity programs, bur we able to draw a few conclusions from the studst that exist. On average, the programs designed diversify the pipeline through active recruitment and programs designed to upgrade extant female nd minority workers (through training), have suc ceeded. Yet programs designed to quell manageria hias, such as diversity training and diversity performance evaluations, have failed to increase workforce diversity. The same is true for bureaucratic personne procedures designed to stop managers from exercising bias. Programs that assign responsibility for diversity to managers (diversity taskforces, diversity managers, mentoring) have helped, while programs designed to increase networking within groups that are not well represented in management (affinity networks or employee resource groups) have no increased managerial diversity. Overall, efforts to interfere with the exercise of managerial bias have failed while efforts to make managers responsible for advancing diversity and efforts to recruit and upgrade women and minorities have succeeded.

\section{The Sociological Approach}

While most of the chapters in this volume report the results of behavioral studies, based in laboratory research or in field research on individual organizations, we review studies using an approach that has become common among sociologists who seek to explain labor market outcomes with organizational characteristics. Our own studies employ data from national samples of hundreds of U.S. employers, over several decades. A number of sociologists employ similar methods (Baron \& Bielby, 1986; Edelman, 1992). Such data allow us to use advanced statistical techniques that permit evaluation of the effects of diversity programs on work force composition over time. Because of the large number of organizations in these samples, and the long time spans they cover, we can isolate the effect of a new diversity program in the years that follow its introduction from the effects of changes in the environment and firm. We can establish whether, on average, mentoring programs lead to changes in the composition of the workforce. We are aided in the task by the availability of time-series data on workforce composition that allow us to observe the baseline level of diversity, and the rate of change before innovations are introduced.

Behavioral studies, such as those reviewed in Chapter 19, "Effective Diversity Training," typically xamine the consequences of diversity innovations in terms of individual behaviors or attitudes. The studies we discuss examine, for the most part, effects of diversity program innovations on workforce composition. They cannot identify the effects of diversity programs on behavior or cognition, but some of these studies help to fill important lacunae in the behavioral literature. For instance, Roberson, Kulik, and Tan report that little research has been done on the long-term behavioral effects of diversity training, or on the group or organizational effects. We report below that diversity training programs have had negligible effects on workforce composition. In addition to establishing the organizational effects of programs, the approach we take can thus help to determine whether behavioral and cognitive effects of innovations translate into changes in the makeup of the workplace.

In the process of reviewing sociological findings about the efficacy of diversity programs, we present graphs tracing the diffusion of different diversity programs among U.S. firms: The data for these graphs come from a retrospecrive survey Dobbin and Kalev conducted together in 2002, and from surveys Dobbin conducted in 1986 with John W. Meyer, W. Richard Scott, and John Sutton, and in 1997 with Erin Kelly. They cover 829, 279, and 389 employers respectively. Each survey was stratified by industry to cover a broad swarh of the U.S. economy (Dobbin et al., 1993, 2007; Kalev \& Dobbin, 2006). We spoke to human resource managers, asking whether and when they had used each employment practice (Dobbin, Edelman, Meyer, Scott, \& Swidler, 1988). We also report some data from Lauren Edelman's (1992) exemplary retrospective survey from 1989. These surveys cover middle-sized to large U.S. employers and have high response rates, and thus are more representative than most cross-sectional studies of corporate practice (see Esen, 2005). To fill in the blanks we report some results from cross-sectional surveys conducted by the Bureau of National Affairs (BNA), the Conference Board, and the Society for Human Resources Management.

Where possible, to evaluate the effects of diversity programs on workforce composition we rely on survey data we collected and merged with data on employment composition generously provided to us by the Equal Employment Opportunity Commission (EEOC) for confidential use under an Intergovernmental Personnel Act agreement. (Kalev et al., 2006). We report findings from some other studies that use employer-provided data on workforce composition (e.g., Castilla \& Benard, 2010; Edelman 
\& Petterson, 1999; Holzer \& Neumark, 2000). Data constraints drive much of the research in this field and consequently limit what scholars and policymakers know about the effects of diversity innovations.

\section{The 1960s: The attack on Jim Crow}

From the time John F. Kennedy signed Executive contractors, private firms took the lead in defining discrimination. The President's Committee on Equal Employment Opportunity, an inter-agency committee with no means to discipline firms, was to oversec compliance. But the privately organized "Plans for Progress" subcommittee, the brainchild of Atlanta lawyer Robert Troutman, did the most to establish standards for fair employment. Within a year Troutman had signed up nearly 100 leading companies that would collaborate in devising strategies for promoting fair employment (Graham, 1990, pp. 33-59) Many of these Plans for Progress firms were military contractors, who faced the threat of contract cancellation that came with Kennedy's affirmative action order of 1961. The fair employment measures they developed spread far and wide in the 1960s, notably corporate nondiscrimination policies, special recruitment programs for minorities, and programs to train new minority recruits and upgrade current workers (Graham, 1990, p. 49; Sovern, 1966, p. 109)

\section{Corporate nondiscrimination policie}

Kennedy's Executive Order required federal contractors to post a notice stating: "The contractor Order 10925 outlawing discrimination by federal

will not discriminate against any employee or applicant for employment because of race, creed, colo or national origin" (New York Times, 1962 p. 29). A company version might have seemed redun dant, but contractors soon wrote nondiscrimination policies of their own for inclusion in their Plans for Progress pledges, personnel manuals, and job advertisements, which now ended with the tag line "An Equal Opportunity Employer in the Plans fo Progress Program" (Bethlehem Steel, 1968, p. 3).

By mid-1965, most of the 300 companies that had signed on with Plans for Progress had their own nondiscrimination policies in place. By 1967,71 percent of medium and large employers surveyed by the BNA had nondiscrimination policies (BNA 1967, p. 10). These spread to smaller employer after 1970. In the 1986 survey (Fig. 15.1), one in five employers reported that they had a writte policy protecting minorities by 1970 , but nearly half reported that they had one by 1980 (Dobbin et al., 1993; Edelman, 1990). Policies covering women lagged behind those covering minorities, for Kennedy's 1961 affirmative action order did not cover sex discrimination. By the turn of the century policies mentioning race and sex were found in more than 90 percent of medium and large employers, according to our 2002 survey (Kalev et al., 2006).

Once the policies were widespread, officials endorsed them. Thus, when the Allen-Bradley Company of Milwaukee was challenged by the Department of Labor in 1968 for discriminating against, blacks, Secretary of Labor George P. Shultz

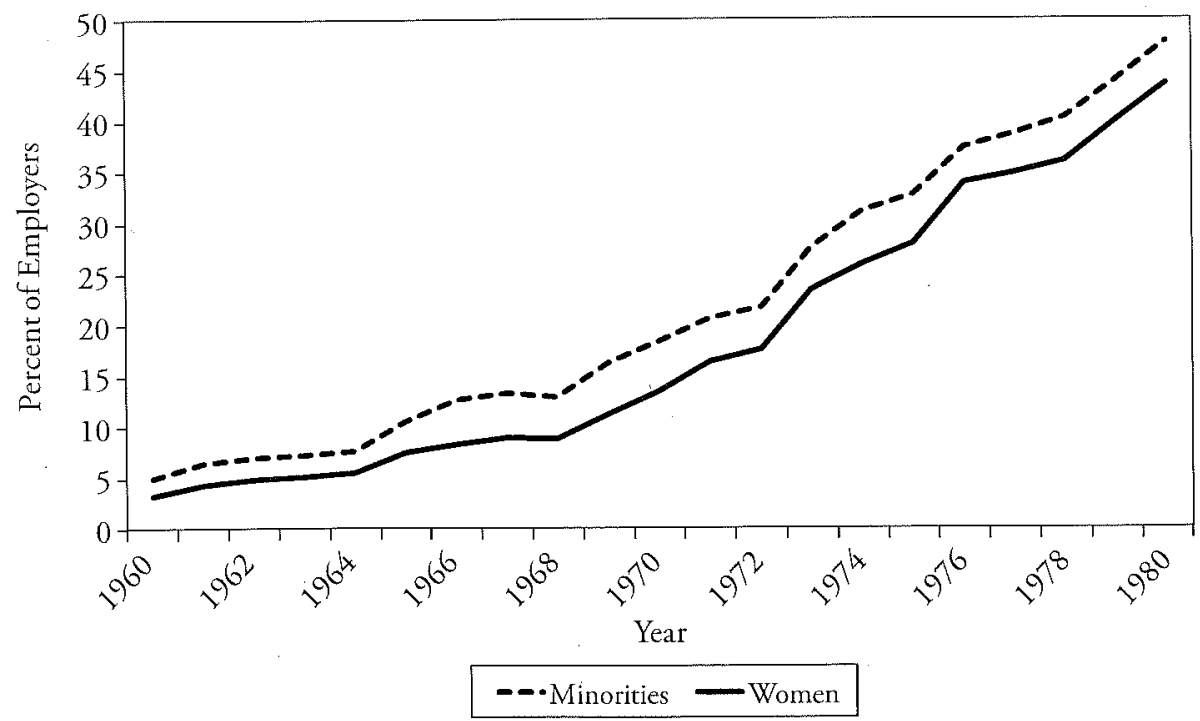

Figure 15.1. Employer antidiscrimination policies.

Source: Survey of 279 employers in 1986 (Dobbin ec al., 1993) said that the company must do as other companies had done and announce a nondiscrimination policy (Shaeffer, 1973).

Despite adopting written antidiscrimination policies, firms continued to trear groups differently. Many continued to advertise jobs for men and women separately, to ban pregnant women from work, and to exclude mothers from certain jobs. In 1966, the EEOC decreed that employers could not ban married women and those with small children, but it let segregated job ads and pregnancy bans stand (Pedriana, 2006). The newly formed National Organization for Women fought the EEOC on these issues, sending picketers to EEOC offices and suing the agency (Danovitch, 1990). By 1969 the EEOC had come out against separate job ads, except where a "bona fide occupational qualification" (BFOQ) limited the job to one sex (Abbott, 1994; Costain, 1992; Harrison, 1988; Pedriana, 2004). According to the guidelines that EEOC lawyer Sonia Pressman drafted, "the only jobs for which sex could be a BFOQ were sperm donor and wet nurse" (1990).

\section{New recruitment programs}

The company recruitment program was the second pillar of the early equal opportunity program. Many leading firms had longstanding recruitment programs targeting white men. They visited the Big Ten to find management trainees and trekked to vocational schools for skilled workers. In 1961, Lockheed established a program to recruit at Atlanta's segregated black high schools and at historically black colleges (Raskin, 1961). Personnel director Hugh Gordon argued that a firm that had practiced Jim Crow had to go the extra mile; "In the

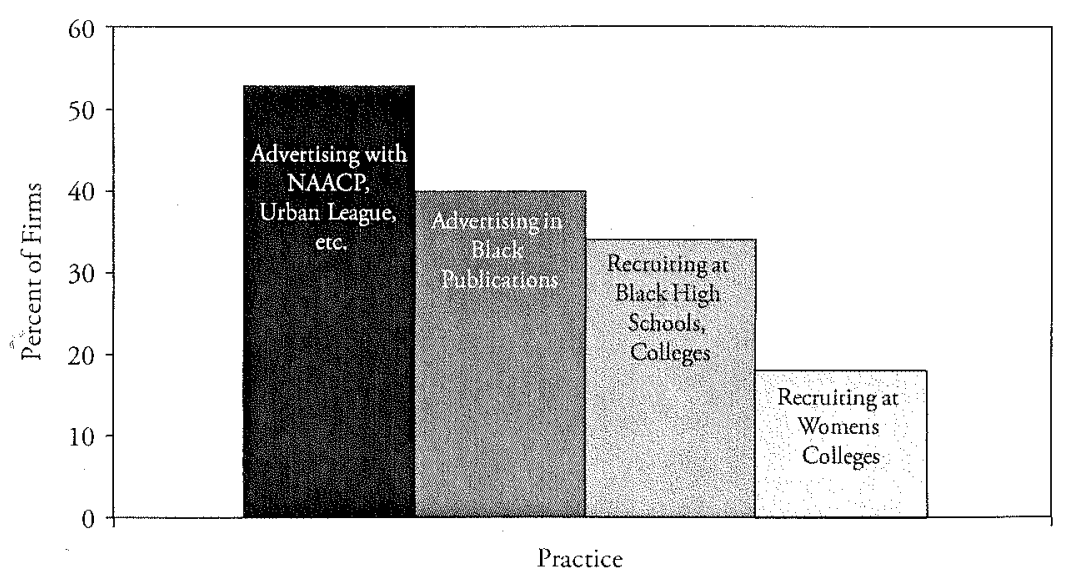

Figure 15.2. Targeted recruitment programs for Blacks, women, 1967. source: Bureau of Narional Affairs, 1967
South... blacks who had been denied jobs just didn't have the confidence... to apply for jobs in companies where they thought they were not wanted. So it's understandable we had to make an effort to get the applicants" (2000). Lockheed brought busloads of black college students from Taskegee Institure in Alabama on recruitment visits (Mattison, 1965, pp. 151-152). By 1963, the New York Times reported that "Personnel officers are taking a new look at their recruiting merhods and seeking advice from Negro leaders on how to find and attract the best-qualified Negroes" (Stetson, 1963, p. 1).

America's historically black colleges now faced an onslaught of recruiters. Fisk College in Nashville saw recruitment visits rise from 27 to 78 between 1963 and 1964. Howard had 400 recruitment visits in 1964 and again in 1965 for a graduating class of 450 (Grove, 1965, p. 32). A 1967 BNA survey (Fig. 15.2) found that among leading employers, 31 percent had created new recruitment systems for blacks between 1965 and 1967 (BNA, 1967, p. 1). More than half of the firms were now advertising through organizations like the NAACP and the Urban League. A third sent recruiters to "predominantly Negro high schools and colleges," and a fifth were recruiting at women's colleges (BNA, 1967, p. 10).

Some executives resisted. One told the BNA that active recruitment of minorities would constitute reverse discrimination: "I have given instructions as of $1965 \ldots$ that if any good Negro applicants appear and if we have any openings, hire them. We have had none during this period ... to go outside our area and recruit them would discriminate against local applicants" (BNA, 1967, p. 3). Resistance was rare among leading firms. A national survey of Fortune 
750 companies in 1969 found that top executives universally believed in special recruitment and training programs, and that just over half of line managers agreed with them (BNA, 1967, 1976). Yet these programs did not become widespread outside of the biggest firms: only one in 10 of the firms in our 2002 national sample had a special recruitment program.

\section{Training for opportunity}

Targeted recruitment programs would not help unskilled African-Americans and Latinos move into skilled jobs. Personnel experts now built on the training schemes devised to address wartime labor shortages, setting up programs to train minorities for clerical and manufacturing jobs they had been excluded from before (Braestrup, 1961). Employers with ongoing skill training and management training programs now pledged to enroll blacks (McFarland, 1965). Others created training programs for the first time, with the goal of upgrading women and minorities, and special programs to attract women and minorities to training.

As of 1960, most companies had not enrolled any women or minorities in management training, according to the BNA studies, but by 1966, 31 percent of large employers offered management training and 21 percent had special programs to enroll minorities in training (BNA, 1967). Between 1967 and 1985, the number of employers enrolling women and minorities in management training and apprenticeships grew steadily (Fig. 15.3). By 2002, our own study shows, 68 percent of firms offered management training and 20 percent of all firms targeted women or minorities for inclusion in management training.
Do equal opportunity policies and targeted recruitment and training work?

The innovations that were popularized in the 1960 s were designed to increase integration of jobs that had been the exclusive province of white men. Perhaps the best measure of the efficacy of these programs, across firms, is whether they are followed by increases in the integration of management jobs, all else being equal. We know of no published research that examines the effect of equal employ. ment opportunity statements on the subsequent employment of women and minorities. However, an unpublished analysis of our own 2002 survey data indicates that the adoption of such statements has not led to change in the demographic composition of management jobs. In models identical to those reported by Kalev and colleagues (2006), we examined the effect of the implementation of an equal opportunity policy on composition of the managerial workforce, in a sample of 814 corporations over the period 1971-2002. Statements are not followed by significant increases in white women in management, or in black, Hispanic, or Asian-American men or women. We suspect that this is because policy statements do not, by themselves, lead to changes on the factory floor. Managers may not know how to ensure equality of opportunity, or they may not be inclined to hire and promote workers from different backgrounds (Kanter, 1977).

The literature provides more evidence on the effects of targeted recruitment, management training, and recruitment into management training. Regarding recruitment efforts, Holzer and Neumark (2000) analyze data from the Multi-City
Study of Urban Inequality, finding that firms that make special efforts to recruit women and minoriies are more likely to hire them. Borh Edelman and Petterson (1999) and Konrad and Linnehan (1995) find that active recruitment and special promotion rograms are associated with increased diversity.

Evidence on management training programs points to a different pattern. Despite being hailed arly on as a strategy for remediating inequality, research suggests that employer-provided training may have worked against equality. Participation in management or skills training does not harm women or minorities, but the groups continue to be enrolled in those programs at lower rates than white men. And training is a stepping stone to advancement. Thus, the 1995 report of the federal Glass Ceiling Commission listed lack of management training as a key barrier in career progression for women, and Knoke and Ishio (1998, p. 162) show that there are significant gender differences in access to company training even within occupations. Employers seem to view training more as an investment in human capital than as a means of equalizing opportunity. They rend to provide training for more educated and higher-status workers (Hight, 1998; Lynch \& Black, 1998), and for those they expect to have continued employment and high productivity not affected by family obligations (Knoke \& Ishio, 1998). These criteria result in statistical discrimination against women (Knoke $8 x$ Ishio, 1998) and minorities (Yang, 2007). Thus, employer-provided training has not lived up to its potential to iron out pre-labor market disadvantages faced by women and minorities (Appelbaum \& Berg, 2001). Yet, most existing evidence comes from research that collapses management training with skill training, and this may conceal effects of management training (Bills \& Hodson, 2007). We need more fine-grained analyses of different types of training.

\section{The 1970s: Expanding the}

\section{labor relations model}

Slow progress on integration in the 1960s spurred the administration, the courts, and Congress to turn up the heat. In 1970 and 1971 the Department of Labor required new workforce reports and new affirmative action plans from federal contractors, and stepped up compliance reviews. In 1971, in Griggs v. Duke Power (401 U.S. 424, 1971), the Supreme Court defined discrimination to include employer practices that were not explicitly exclusionary but that had a "disparate impact" on women or minorities. In 1972 Congress expanded the coverage of Title VII and gave the EEOC the authority to sue employers. In the context of recent racial strife in big cities, and the establishment of the National Organization for Women, these changes emboldened personnel experts to propose new compliance measures.

\section{Equal opportunity specialists and departments: Creating organizational responsibility}

From the early 1960 s, new workplace regulations of all sorts stimulated firms to hire a variety of compliance experts (Kochan \& Cappelli, 1984, p. 146). Whereas the Department of Labor enforced 16 statutes and executive orders in 1940 and 50 in 1960, by 1977 it enforced more than 130, including affirmative action regulations (Foulkes \& Morgan, 1977, p. 171). The Department recommended that firms appoint affirmative action officers to handle compliance, and consultants insisted that middle-sized to large firms would need their own departments (Boyle, 1973). A 1977 article in the Harvard Business Review advised: "The various requirements of state and federal regulations... make increasing demands on both profit and nonprofit organizations... Compliance with the laws relating to OSHA, EEOC, and ERISA demands expertise;" only specialists could keep track of "what is happening in the outside world" in terms of regulation and employer response (Foulkes \& Morgan, p. 160). More and more companies followed General Electric, which had set up a separate equal opportunity office in 1968 , with subcommittees to handle everything from compliance reviews to "social awareness" training (Schofer, 1971)

Organizational scholars have long recognized that firms create departments to mirror the players they face in the regulatory environment (Lawrence \& Lorsch, 1967; Thompson, 1967). Jeffrey Pfeffer described department creation as a form of "protest absorption," which could allow unionists to appeal to labor relations departments and minorities to pursue "their interests through affirmative action offices" (Pfeffer \& Salancik, 1978). John Meyer and W. Richard Scott (1992, p. 275) describe this pattern as uniquely American, for the fragmented character of the federal regulatory environment leads to distinct corporate departments to "symbolize safety, the environment, affirmative action" and so on.

A study from the late 1980s of 141 Tennessee manufacturers with at least 100 workers found 


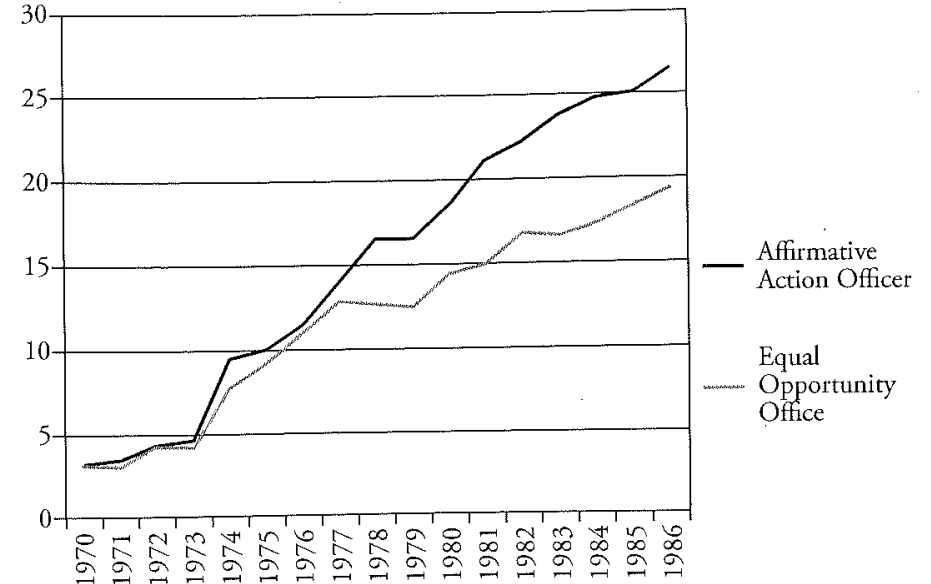

Figure 15.4. Antidiscrimination departments and officers.

Source: Survey of 279 employers in 1986 (Dobbin et al., 1993). Some organizations were not in operation ac the beginning of the period. The denominatoo varies over time.

that over half had affirmative action offices (Johns \& Moser, 1989). In Dobbin's collaborative 1986 survey of middle-sized to large employers, only 4 percent had equal opportunity offices or affirmative action officers by 1972. By 1986 these numbers rose to 20 percent and 25 percent respectively (Fig. 15.4). A similar pattern is evident in Lauren Edelman's national survey from 1989 (1992, p. 1555).

\section{Equal opportunity performance evaluations: Monitoring} individual managers

Once firms had specialists charged with developing antidiscrimination programs, they turned to the task of bringing line managers on board. Industrial psychologist Theodore Purcell championed the General Electric model, in the Harvard Business Review in 1974, of making managers accountable through a "measurement system with rewards and penalties designed to produce behavioral changes" (1974, p. 99). The equal opportunity performance evaluation was modeled on the merit rating systems that unions had lobbied for, and lined up nicely with the new financial performance systems conglomerates were using to judge managers (Baron, Jennings, \& Dobbin, 1988; Jacoby, 1985).

Every one of the 20 leading firms that the TowersPerrin consultancy studied in 1973 made equal opportunity part of the formal annual performance evaluation (Fretz \& Hayman, 1973). A company president argued that firms must "place responsibility for achieving equal opportunity objectives where it rightfully belongs, with operating management, with each of us" (Ackerman, 1973, p. 94). In the BNA's 1975 study of leading firms, four in ten manufacturers, three in ten service firms, and two in ten nonprofits had equal opportunity performance evaluations (Bureau of National Affairs, 1976). In our 2002 survey, with a more representative sample that includes some smaller firms, only 4 percent of the sample had evaluations by 1985 , but by 2002 nearly one in five firms had them.

\section{Does responsibility breed diversity?}

The 1970s brought to life two mechanisms for assigning responsibility: one created an organizational structure, a department or a position, and the other took the individualized form of evaluating managers' diversity efforts. Evidence suggests that the structural approach has been significantly more effective. Edelman and Petterson (1999) show that while equal opportunity departments do not increase gender and racial diversity on their own, they do expand diversity recruitment programs. which in turn improve diversity. In our analysis of data on more than 800 employers between 1971 and 2002 (Kalev et al., 2006), we find that the hiring of an equal employment opportunity specialist has sig. nificant positive effects on the subsequent share 0 women and minorities in management. Figure 15:5 shows that the appointment of a full-time diversity staffer leads, in the average firm, to a 10 percent increase in the proportion of white women in man agement and a 15 percent increase in the proportions of both black men and black women. These effects take place over about 5 to 7 years.

Diversity performance evaluations show weal and mixed effects on managerial diversity according

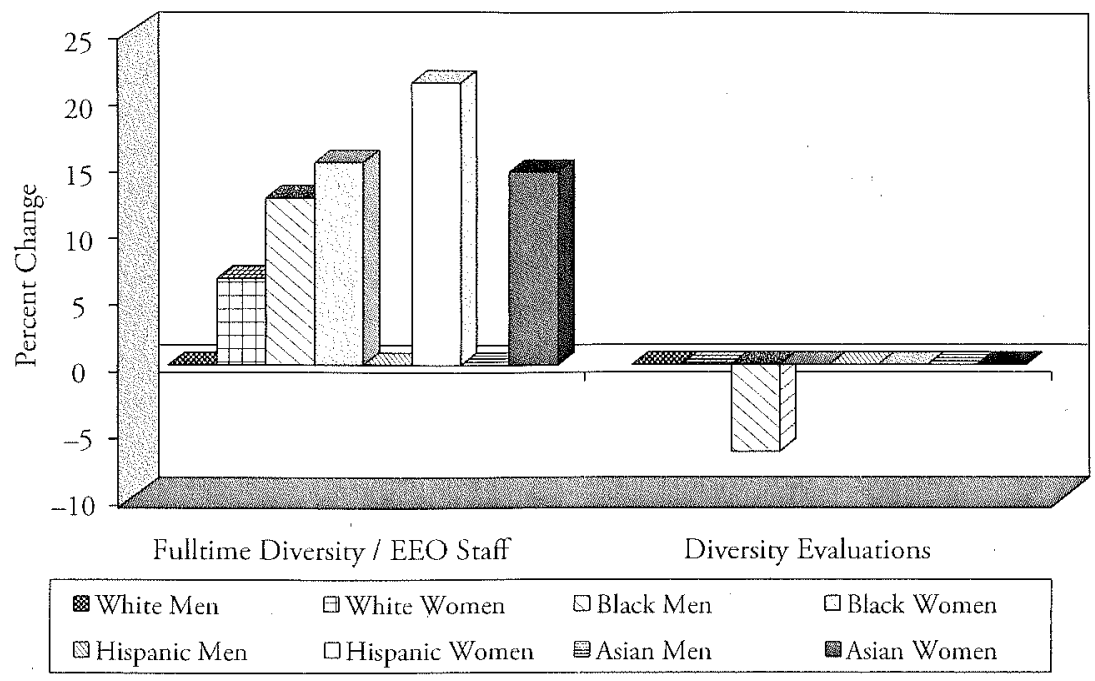

Figure 15.5. Effects of diversity staff and diversity performance evaluations.

to the same study. Firms that create diversity performance evaluations see small decreases in the share of black men. However, in the presence of formal oversight, through a full-time diversity staffer or taskforce, diversity performance evaluations exhibit no negative effects (Kalev et al., 2006). Diversity performance evaluations may have adverse effect because they alienate managers, but monitoring can prevent those effects.

\section{Bureaucratic biring and promotion: Tying}

\section{the bands of managers}

In the early 1970 s, federal courts and Washington regulators identified hiring and promotion practices as a source of discrimination. The Supreme Court's 1971 Duke Power decision, challenging seemingly neutral job tests, led firms to scrutinize personnel routines generally. Then EEOC-brokered civil rights consent decrees called for modernization of hiring and promotion. In settlements with some of America's leading firms, across industries ranging from banking to steelmaking to trucking, the EEOC secured pledges to formalize salary assignment and promotion (Fehn, 1993; Shaeffer, 1975).

Personnel experts responded by developing a civil rights compliance arsenal based on the labor relations model. Unions had lobbied for bureaucratic procedures, from job posting to promotion rules, to prevent discrimination against unionists (Jacoby, 1985). Many of the same procedures might help to fight racial, ethnic, and gender discrimination. Fornal personnel systems would also leave a pape trail, which would be useful in the case of lawsuits and would help employers meet reporting requirements (Thorpe, 1973, p. 649).

Some experts argued that job tests could prevent discrimination, but cautioned that employers should not use popular tests that served as high school equivalency exams, because inequality in educational opportunity left many blacks disadvantaged by such tests (Skrentny, 1996, p. 97). In 1960, 35 percent of white adults but only 23 percent of blacks had finished high school (Bureau of the Census, 1975, p. 380, Part I). Moreover, segregated black schools were chronically underfunded. Tests should therefore be tightly linked to job content. In 1966, Personnel Psychology championed validation of job tests to ensure that they predicted performance and did not simply exclude applicants who had attended inferior schools or dropped out (Dugan, 1966; Lopez Jr., 1966; Parrish, 1966). Later that year, the EEOC issued guidelines specifying that tests should be statistically validated to predict job performance (Thorpe, 1973, p. 647)

After 1971, when the Supreme Court found that general tests of academic skills could be discriminatory if they were not predictive of job performance (Griggs v. Duke Power, 401 U.S. 424 1971), personnel experts advised employers to either validate tests or get rid of them (Campbell, 1973; Gavin \& Toole, 1973; Gorham, 1972; National Civil Service League, 1973; Slevin, 1973). Some employers validated, although many, including some of the largest police and fire departments, continue today to use unvalidated tests. Yet the ruling had a chilling effect on test creation. Both job and promotion tests languished after 1971, making tests the exception 


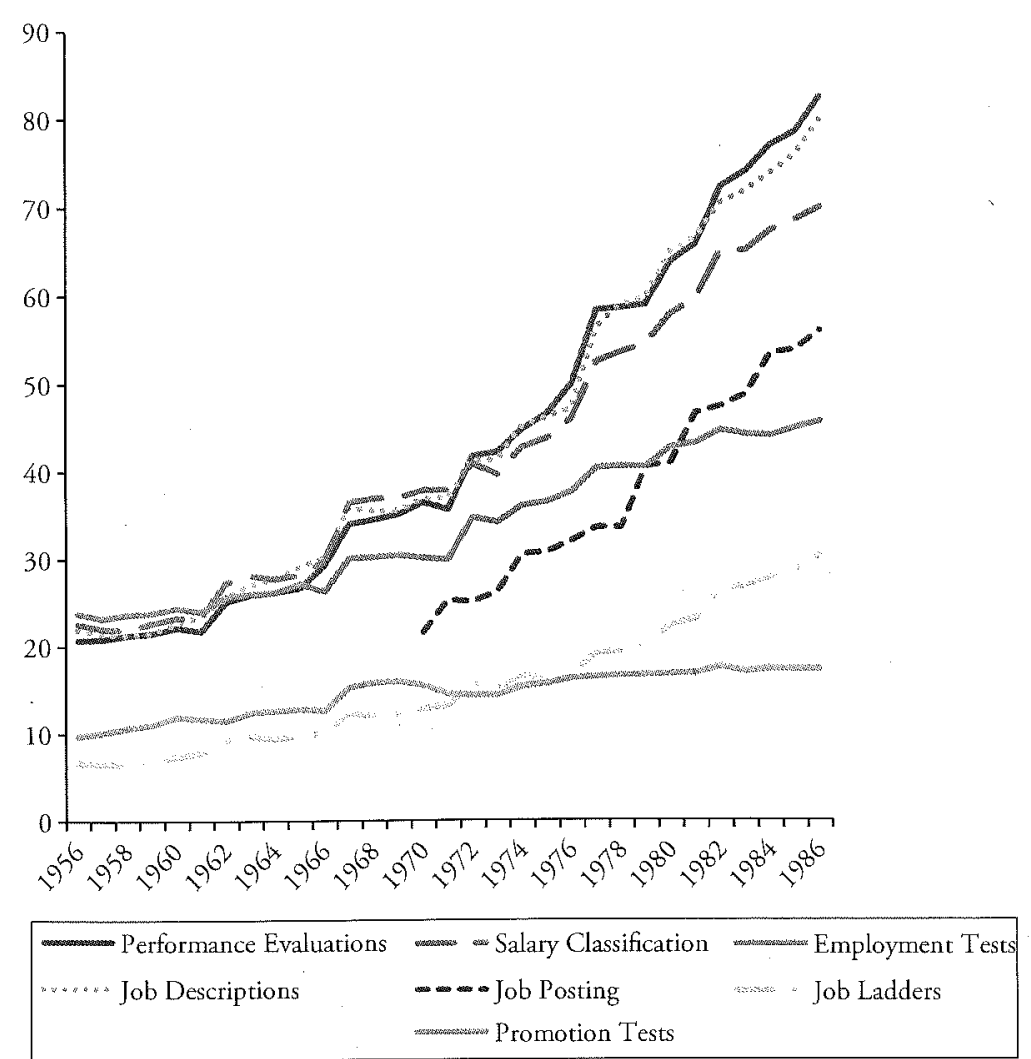

Figure 15.6. Bureaucratic hiring and promotion practices.

Source: Survcy of 279 employers in 1986 (Dobbin et al., 1993). Job posting is taken from our 2002 survey (Kalev er al., 2006).

that proves the rule that employers adopted bureaucratic procedures to comply with equal opportunity laws. Job tests were one of the two early bureaucratic personnel practices that did not spread rapidly (Fig. 15.6), for they were not part of the "equal opportunity" prescription.

Personnel experts had mixed advice about job ladders, which specified promotion trajectories from entry-level jobs. Women and blacks were often crowded in jobs with no rungs above them, and so experts advised firms to abolish existing ladders and restructure them so that female- and minority-dominated jobs had gateways that led upward (DiPrete, 1989, p. 197). Another remedy was to replace job ladders with open bidding, "so that all employees are aware of vacancies as they occur and that promotion into these vacancies is based on qualifications, not sex" (Slevin, 1973, p. 30). Dobbin and colleagues' 1986 survey shows that the pattern of diffusion of job ladders looks more like job tests than like the other bureaucratic procedures (see Fig. 15.6). This was the second bureaucratic personnel procedure that did not spread apace.
Executives read that the EEOC favored job post ing, and that it could prevent cronyism (Fulmer \& Fulmer, 1974, p. 492). They also began to hear complaints that supervisors kept news of openings from women and minorities in the workforce. Unions had long demanded formal job posting systems to prevent managers from blackballing unionists (1974, p. 493). Equal opportunity experts now proposed open job posting on the union model. According to our 2002 survey, two in ten companies had policies requiring posting of jobs as of 1971 and nine in ten companies had them three decades later (see Fig. 15.6 for the trend from the 2002 data up to 1986).

In 1962 it came out that supervisors at severa Louisiana oil refineries had excluded blacks from skilled jobs by inflating educational prerequisites for jobs. Personnel experts recommended written job descriptions, specifying prerequisites, that would be available to jobseekers (Boyle, 1973, pp. 94-95). Among the medium-sized and large employers in the 1986 survey, the use of job descriptions had risen gradually between 1956 and 1966, from 22 percent to 28 percent (see Fig. 15.6). But over the next 20 years, job descriptions caught on. Eight out ten of these firms used written job descriptions by 1985 .

Since the 1930s, management and personnel journals had extolled annual, written performance evaluations for use in promotion, pay, and disciplinary decisions (Cunningham, 1936; Drum, 1960; Patton, 1960; Rock \& Grela, 1960). In the early 1970 s, several firms were charged with employment discrimination for letting managers' informal views taint promotion decisions (Rowe $\nu$. General Motors Corp., 457 F.2D 348, 359, 5 Cir 1972). Experts now argued that a written annual performance evaluation, with objective output measures, could fight prejudice (Peskin, 1969, p. 130). A 1974 article in Personnel suggesced: Performance reviews should ... be based on solid riteria available to all concerned parties," to ensure that promotion decisions were based on abilitywhich, "coincidentally," conforms to the EEOC's ridelines (Froehlich \& Hawver, 1974, p. 64). The BNA (1967, p. 16) found that companies were creating performance evaluations to stem discriminaiion. The 1986 survey shows that between 1956 and 1966, the prevalence of evaluations rose from 20 percent to 25 . At that rate, 35 percent of firms would have had them by 1986 . Instead, 80 percent of employers had installed them by then (see Fig. 15.6)

The Equal Pay Act required employers to pay the same wages to men and women doing the same work, and the Civil Rights Act outlawed discrimination in the terms and conditions of employment. Yet firms continued to pay different wages for the ame work. In 1974, the Supreme Court ruled hat employers could not pay women less than men by assigning them different job titles "simply because men would not work at the low rates paid women" (Corning Glass Works v. Brennan, 1974). Union-inspired salary classification systems established skill, education, and experience requirements, lacing like jobs into wage bands. Discrimination plaintiffs now asked for salary classification systems in their settlement negotiations (Shultz $v$. Wheaton Class Co., 421 F.2d 259 3rd Cir 1970).

Personnel experts advised firms to classify all jobs to ensure that pay rates were not discriminatory (Chayes, 1974, p. 81; Giblin \& Ornati, 1974). About one third of employers reported that they had salary classification systems in the early 1970 s and some 70 percent had them by the mid-1980 (see Fig. 15.6). For comparison, employment tests started at about the same place but reached only 45 percent of employers by the mid-1980s.
When the administration, the courts, and Congress stepped up enforcement of fair employment laws in the early 1970s, personnel experts promoted a new round of compliance strategies. The picture drawn by national surveys confirms that the union personnel model was now used as a civil rights antidiscrimination system, and spread across firms despite the fact that unionization was declining. Seventy to eighty percent of employers had put in performance evaluations, job descriptions, and salary classification systems by the mid-1980s, up from 30 percent or less at the beginning of the 1970s. Job posting systems and centralized hiring and firing were not far behind. These practices left Americans with new ideas about workplace fairness. Bureaucratic rules governing hiring and promotion were supposed to quash bias and create a level playing field.

\section{Does bureaucracy promote diversity?}

Theorists offer conflicting predictions about the effects of formal hiring and promotion practices. Feminist scholars have argued that bureaucratic rules may reinforce the status quo in organizations. In The Feminist Case Against Burreaucracy, Kathy Ferguson $(1984$, p. 7) argues that bureaucracy creates a "scientific organization of inequality." Joan Acker (1990) argues that "rational-technical, ostensibly gender neutral, control systems [in organizations] are built upon and conceal a gendered substructure." Hiring and promotion procedures can codify disadvantage in formal organizational structure rather than reduce inequality by, for instance, formalizing selection criteria that advantage white men. Thus, job descriptions that require a decade of continuous service tend to advantage men, because women more often experience career disruptions following childbirth. Yet some social psychologists expect formal personnel procedures to quash discrimination by reducing managerial discretion and the operation of cognitive bias (Bielby, 2000; Reskin, 2000).

Evidence of the effects of bureaucratic practices is scant, indirect, and inconsistent. Most studies rely on cross-sectional data from employers, or short panel series, and use counts of formal personnel practices, failing to differentiate effects of particular practices. Several cross-sectional studies suggest that bureaucratic practices may promote equality, but it is difficult to know whether the bureaucratic practices are the cause or the consequence of workforce integration, or whether both are a consequence of a third factor. Reskin and McBrier (2000) find that large employers with formal personnel procedures have 
more women in management, and Walker (1990) finds that they have more black men on the job. Anderson and Tomaskovic-Devey (1995) find lower wage disparities among employers with more formal personnel procedures. In one of the few studie using longitudinal data, Baron, Hannan, Hsu, and Koçak (2007) find that firms founded with bureaucratic personnel systems have more women workers 6 years out. Elvira and Zarzick (2002) find that some minorities fare better when personnel decisions are bureaucratized.

Other studies have found that formal personnel systems are not associated with greater equality, notably those by Edelman and Petterson (1999), Konrad and Linnehan (1995), and Huffman and Velasco (1997). Yet others have identified mechanisms through which bureaucratic practices may thwart equality of opportunity. Next we discuss some of these studies in the process of reviewing evidence about the effects of individual practices.

Despite the Supreme Court decision in Griggs. v. Duke Power Company, many employers continue to use job tests that have not been validated. The human resources director at a medium-sized New Jersey manufacturer, without a federal contract, reported in an interview we conducted in 1999 that he used an unvalidated test to assess math skills: "We'll throw ourselves on the mercy of the court if anything happens." Research by psychologists shows that cognitive ability tests disadvantage minorities, particularly blacks and Hispanics (Roth, Huffcutt, \& Bobko, 2003; Hough \& Oswald, 2000). In a study of employer selection methods in Canada, based on survey data from 154 organizations, $\mathrm{Ng}$ and Sears (2010) find that cognitive ability testing is associated with lower minority employment in general and in management. They also find that firms covered under employment equity legislation were less likely to use such tests.

DiPrete (1989, p. 197) argues that the problem with job ladders is that they often exclude from promotion lines the entry-level jobs dominated by women and minorities. Such exclusionary jobladders help to explain the gender gap in promotion in the federal civil service in the 1970 s (DiPrete \& Soule 1988). In their analysis of promotions in an insurance company between 1971 and 1978, Spilerman and Petersen (1999) find that women were handicapped by being in jobs with short promotion ladders. The EEOC's 1974 consent decrees with the leading steelmakers recognized that constrained job ladders had harmed blacks, and mandated the replacement of department- with plant-level caree systems and seniority. Blacks had been relegated o departments without skilled jobs, and hence had nowhere to move from the entry-level labore jobs. Ichniowski's study shows that the switch to plant-wide promotion systems, which ended con straining job ladders, led to significant increases in the share of minorities in skilled jobs (Ichniowst 1983).

Job posting systems require managers to notify existing workers, through posting, of job open ings within the firm. Reskin and McBrier (2000) find more women in management in organizations that use open recruitment methods, including job posting. But job posting systems can be thwarted by managers who favor white men. Pager, Western, and Bonikowski (2009) show that managers make biased hiring decisions when sorting applicants who respond to job advertisements. Whites are more likely to receive callbacks or job offers, and blacks and Hispanics who do receive job offers are rele gated to lesser jobs. Job posting thus may not reduce inequality.

Some consultants caution that job descrip. tions can hamper women and minorities by settin prerequisites that favor white men (engineering degrees, long uninterrupted service) but that are no essential to job performance (Boyle, 1973, p. 91) Job descriptions have also been linked to slow advancement of women and minorities bunched in narrowly defined jobs outside of promotion ladders (Baron \& Bielby, 1986, pp. 479-495; Strang \& Baron, 1990; Tomaskovic-Devey \& Skaggs, 1999). Proliferation of narrow job titles, which is associ ated with job descriptions, may also reduce the perception of unfair treatment and thereby "coo out" ambitious women and minorities (Baron \& Pfeffer, 1994).

Performance evaluations have been subjected to perhaps the closest scrutiny. Field and laborator studies challenged "objective" performance evaluations, suggesting that they cannot prevent raters from exercising race and gender bias (Hamner, Kim Baird, \& Bigoness, 1974; Kraiger \& Ford, 1985 Nieva \& Gutek, 1980; Oppler, Campbell, Pulakos, \& Borman, 1992; Pulakos, White, Oppler, \& Borman, 1989; Tsui \& Gutek, 1984). Meta-analyse show a persistent gap in ratings of black and white workers (Roth, Huffcut, \& Bobko, 2003; Mckay $\&$ McDaniel, 2006). Some of the racial gap is dur to the race of raters- whites tend to give higher rat ings to other whites, blacks to other blacks (Kraige $\&$ Ford, 1985)—and most real-world managers arc white (Elvira \& Town, 2001). Both laboratory and eld studies also find gender bias in performance atings (Bartol, 1999).

Research also shows that firms may ignore ratngs and make personnel decisions based on stereowpes (Auster \& Drazin, 1988; Castilla \& Benard, 2010; Elvira \& Zatzick, 2002) or apply different standards when evaluating ratings of white men and athers (Castilla \& Benard, 2010; Roscigno, 2007, Chapter 8). Louise Roth's (2003, p. 180) analysis of the gender pay gap on Wall Street shows that compensation based on performance evaluations harms women, whose contributions are often underestirated (see also Kanter, 1977). Auster and Drazin 1988) and Castilla and Benard (2010) find that when men and women have identical performance ratings, men receive larger raises. Elvira and Zatzick (2002) find that blacks' performance scores were significantly lower than whites', controlling for lagged performance, tenure, salary, job, position, and peronal characteristics. Roscigno's (2007) analysis of ivil rights complaints data shows that minority workers are judged more severely than their white counterparts for sub-par performance. Castilla and Benard (2010) find, in a laboratory study, that bonu pay based on performance evaluations is biased in avor of men when a meritocratic organizational culture is emphasized. The authors term this firiding "the paradox of meritocracy." Susan Bisom-Rapp's (1999) analysis of defense attorneys' advice to employer shows that performance evaluations are treated as a preventative tool" (1999, p. 995), wherein managers earn how to write performance evaluations that wil upport their promotion and discharge decisions and revent legal liability. Taken together, performance ating systems may create the appearance of meritocacy without actually undermining discrimination. ggainst these studies there is Dencker's (2008) examation of promotions during corporate restructurings, which shows that firms that base their personnel decisions on performance evaluations, rather than eniority, promote more women.

Experts have argued that salary classification systems sometimes formalize, and perpetuate, wage and rank differences based on the race and gender composition of jobholders (Boyle, 1973, p. 89). The little evidence we have suggests that salary classificarion systems devalue work done by women and minorities. Plaintiffs in a number of civil rights case have claimed that salary classification systems have systematically ranked male-dominared jobs higher than comparable female-dominated jobs (Nelson \& Bridges, 1999, p. 43). Nelson and Bridges further argue that court rulings in favor of employers in such cases have helped to institutionalize salary classification systems as equal opportunity compliance measures, despite a lack of evidence that they fight wage inequality. Moreover, while salary classification systems are touted for the capacity to eliminate managerial bias in wage-setting, in practice they typically permit managerial discretion. In one service sector firm studied by Towers-Perrin consultants, "authorized officers of a certain accountability and responsibility level were in the annual salary range of $\$ 14,000-\$ 21,000$. There were two exceptions-borh females-who were placed in the $\$ 12,000-\$ 18,000$ range, and, to make matters worse, they were paid $\$ 10,600$ and $\$ 10,900$ respectively" (Fretz \& Hayman, 1973, p. 137).

Despite the evidence that formal salary systems may not eradicate wage inequality, some research suggests that they reduce inequality relative to compensation systems that rely entirely on supervisory discretion. Elvira and Graham (2002) look at data for more than 8,000 employees in a finance firm, finding that the remuneration disparity between men and women is greater for bonuses and incentive pay, distributed without formal rules, than for base salary and merit raises, subject to formal rules, even after actual performance is controlled.

Taken together, the extant evidence on the effects of formal personnel procedures on workplace equality of opportunity confirms most of the misgivings personnel consultants had about these programs in the 1970s, as well as predictions made by feminist scholars of bureaucracy. None of the bureaucratic procedures has shown a consistently positive effect on workforce integration, and negative effects are commonly observed. We need more systematic research on the workings of each of these procedures and on the institutional and organizational conditions that mediate their effects on the workforce.

\section{The 1980s: Reagan and the rebranding of \\ equal opportunity}

Ronald Reagan campaigned in 1980 on a promise to dismantle the federal regulations he blamed for the staglation of the 1970s, and fair employment regulations were high on that list. Less than a decade after the Nixon administration worked out the contours of affirmative action compliance, the system was under attack. Reagan criticized affirm ative action's "bureaucratic regulations which rely on quotas, ratios, and numerical requirements" (Blumrosen, 1993; McDowell, 1989, p. 34; Skrentny, 1996). His three main assaults on affirmative action floundered, but they signaled 
that the days of affirmative action enforcement were numbered (Edelman, 1992, p. 1541). He proposed to relieve three quarters of federal contractors from the obligation to write affirmative action plans in 1981, but his deputies balked. He proposed to close the Office of Federal Contract Compliance Programs, which monitors affirmative action, but faced opposition once again from some on his own staff (DuRivage, 1985, p. 368). Then he proposed to end Nixon-era goals and timetables for private firms, but moderates killed that proposal as well (Belz, 1991; Detlefson, 1991, p. 151; Harvard Law Review, 1989, p. 662; McDowell, 1989). Clarence Thomas, the new EEOC head, did curtail enforcement (Blumrosen, 1993, p. 270; Skrentny, 1996). At the same time, Department of Labor oversight of federal contractors was cut back, and both regulatory agencies saw budget and staff cuts (Anderson, 1996; DuRivage, 1985; Edelman, 1992; Fox, 1981; Leonard, 1989; Mayer, 1981; Skrentny, 1996).

Personnel experts responded by rebranding equal opportunity programs in two ways. They folded some programs (performance evaluations, salary classification) into the new "human resources management" paradigm, which looked a lot like classical personnel administration. Other programs they rebranded as part of "diversity management," designed to create "strategic advantage by helping members of diverse groups perform to their potential" (Conference Board, 1992, p. 11; Kossek \& Lobel, 1995; Leach, George, Jackson, \& LaBella, 1995; Miller, 1994).
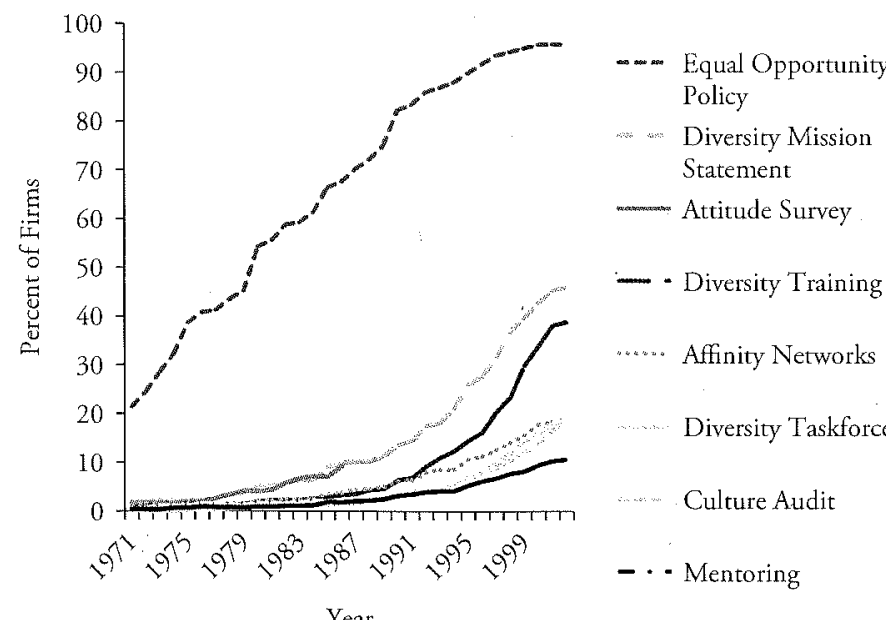

Figure 15.7. Diversity and equal opportunity programs compared.

Source: Survey of 829 firms in 2002 (Kalev \& Dobbin, 2006). Atritude surveys are from survey of 279 employers in 1986 (Sutton, Dobbin, Meyer. \& Scotr, 1994).
Equal opportunity experts became diversity man: agement consultants (Thomas, 2004). Leadin firms had created race relations workshops in the early 1960s, and these now became diversity training seminars. Soon experts were promoting new programs, such as affinity networks and mentoring programs, as part of the diversity management system (Edelman, Fuller, \& Mara-Drita, 2001; Kelly \& Dobbin, 1998).

\section{From equal opportunity policies}

\section{to diversity mission statements}

By the end of the 1970s, one in two medium-sized firms had an equal opportunity policy in place. New diversity mission statements of the 1980 s touted the business necessity of managing diversity and added some new categories of workers to the list of race color, creed, sex, and age, or left out mention of the categories altogether. Over half of the large firms sampled for a 1991 Conference Board survey had a diversity mission statement (Conference Board, 1992, p. 21). In our 2002 national sample, 40 percent of medium and large firms had one (Fig. 15.7). Firms added these on top of their equal opportunity statements to signal that they were not just interested in legal compliance.

\section{From race relations workshops}

\section{o diversity training}

Plans for Progress employers added race relations sessions to their management training curricula at the dawn of the 1960s (Boyle, 1973, p. 87). Soon ederal agencies hired the same trainers to enlighten ederal employees. By 1972, 50,000 Social Security Administration staffers had completed similar workshops. When the BNA surveyed industry leaders in 1976, it found that nearly 70 percen offered equal opportunity training for manager BNA, 1976, p. 9)

In the 1980 s, consultants distanced fair employment training from its origins in the law with the rew moniker "diversity training" (Edelman, Fuller 8x Mara-Drita, 2001). By 2006, a North Carolina food processing executive we interviewed told us that his trainings did not focus on race and sex: "Differences - that was the biggest thing that they taught. Not necessarily white/black, female/male. It was more about everybody is different. Tall, short, some people wear glasses. Some are bald." Yet in the late 1990s human resources manager still listed legal protection as the prime reason for using diversity training (Jordan, 1998). By 2002 only 20 percent of companies in our national sample used training that was devoid of legal or procedural content.

A 1991 Conference Board survey found that 3 percent of big firms offered diversity training (Winterle, 1992, p. 21). Surveys that included medium-sized firms arrived at a number of abou 30 percent by the early 1990 s and about 40 percent 10 years later (Rynes \& Rosen, 1994). In the broad national sample from 1997, nearly half of employers had diversity training. Our 2002 study shows that they continued to spread, although in that later sample, the firms were smaller and hence less likely to have diversity training in place by 1997 (see Fig. 15.7).

\section{From attitude surveys to}

diversity culture audits

Attitude surveys had been a mainstay of personnel management since the 1920s. In the 1960s, Harold Guetzkow (1965) argued that they expand efficiency by improving communication between porkers and management. Federal contractors used surveys of attitudes on race relations from the early 1960s to identify problems at work, and now diversity managers relabeled these as "diversity culture audits," adding questions about gender culture and harassment (Cross, 1996; Lynch, 1997; MacDonald, 1993; Rowe \& Baker, 1984, p. 33; Thomas, 1991). In the 1986 survey, nearly 10 percent of employers were using attitude surveys, and in our 2002 survey, hearly 20 percent of firms were using culture audits see Fig. 15.7).

\section{From equal opportunity taskforces to}

\section{diversity taskforces}

By the late 1960s, several large military contrac tors had established interdepartmental equal opportunity taskforces to devise strategies for promoting workforce integration (Schofer, 1971). By the early 1980 s, diversity experts heralded diversity taskforces (Gant \& Gentile, 1995). Some companies simply renamed the equal opportunity taskforce. The idea was to hold regular meetings among people from different departments who would talk over problems faced by the firm, brainstorm for solutions, and then implement those solutions in their own departments (Sturm, 2001).

By 1991, a survey by the Conference Board showed that one third of America's biggest firms had taskforces (Conference Board, 1992, p. 21). The 2002 survey shows that taskforces began to spread in the wider population of firms in the late 1980s (see Fig. 15.7)

\section{Diversity management innovations:}

\section{Mentoring and networking programs}

Network theorists in sociology argued from the early 1970s that people find jobs through network contacts, and that promotions depend as much on who you know as on what you know (Baron \& Pfeffer, 1994; Castilla, 2005; Granovetter, 1974; Kanter; 1977). While white men often have ties to other white men in positions of advantage (Burt, 1998; Reskin \& McBrier, 2000), women and minorities are often stymied in job search and advancement by poor contacts with those in power (Blair-Loy, 2001; Burt, 1998; Ibarra, 1992, 1995; McGuire, 2000; Petersen, Sapotta, \& Seidelm, 1998). From the early 1980s, diversity managers and workers themselves called for affinity networks, each of which brought together members of one identity group for counsel and support.

Management psychologists had argued for formal mentoring programs that could extend the advantages of mentoring to the historically disadvantaged (Lunding, Clements, \& Perkins, 1979; Roche, 1979). Formal mentoring programs match aspiring managers with volunteer mentors (Burke $8 x$ McKeen, 1997; Burt, 1998; Moore, 2001; Neumark \& Gardecki, 1996; Thomas, 2001). A study from the early 1980s of nine firms famed for their commitment to fairness found that every one promoted mentoring (Vernon-Gerstenfeld \& Burke, 1985, p. 67). By the early 1990s, two studies showed that 20 to 30 percent of America's biggest firms had formal mentoring programs (Conference Board, 
1992). In our broader sample of American firms, only 2 to 4 percent had networking and mentoring for women and minorities by 1990 , but 10 percent had mentoring and 18 percent had networking by 2002 (see Fig. 15.7).

In the $1980 \mathrm{~s}$, the language of affirmative action gave way to a rhetoric of diversity management. Yet a Conference Board researcher argued: "Although there is a strong sentiment that diversity moves far beyond compliance, at this point, practices demonstrate a strong link between the two" (Wheeler, 1994, p. 7). Many core diversity management programs were born of efforts to conform with antidiscrimination programs.

\section{Diversity programs and workforce diversity}

Extant statistical analyses suggest that the diversity management revolution brought a number of new programs to leading American firms, but that those programs had modest effects on workforce diversity (see Figure 15.8). In particular, what was arguably the flagship practice, diversity training, did not lead to increases in managerial diversity. Similarly, the much-celebrated networking programs, labeled "affinity groups" or "employee resource groups," did not foster inclusion in the management ranks. By contrast, diversity taskforces, one of the least costly and least prevalent measures, show strong positive effects on the share of women and minorities in management. Mentoring programs as well have been effective.

In studies of a national sample of 830 employers between 1971 and 2002, we find that diversity training (offered either to all employees or to all managers) has little aggregate effect on workforce diversity (see Fig. 15.8). Training programs show statistically significant, yet substantively negligible, effects on two groups. Training is followed by a 7 percent decline in the proportion of black women and a 10 percent increase in the proportion of Hispanic women in management (Dobbin, Kalev, \& Kelly, 2007). Previous studies had similarly found little effect of diversity training, although most focused on short-term changes in attitudes and self-reported behavior, not on workforce composition over decades (Kraiger, Ford, \& Salas, 1993; Kulik \& Roberson, 2008). These studies are discussed in Chapter 19 by Roberson, Kulik, and Tan.

In contrast to the apparent failure of diversity training to boost diversity, diversity taskforces show strong positive effects on diversity. An analysis of our 2002 survey data shows that following the establishment of diversity taskforces, firms see significant increases, among managers, in white women, and in black, Hispanic, and Asian men and women (Dobbin et al., 2007). Furthermore the presence of a diversity taskforce in an organization improves the operation of most other diversity programs.

The finding that both diversity staff membets and diversity taskforces have positive effects on managerial diversity, and that each of these innovations tends to improve the operation of other diver sity programs, suggests that assigning responsibility for managing diversity to a full-time manager or a group of managers is more effective than measures that individualize blame for disparities, such as diversity performance evaluations or diversity training.

In interviews we conducted with human resources and line managers at 64 workplaces in Atlanta, Boston, San Francisco, and Chicago, respondents reported that taskforces are effective because they identify specific problems and remedies. If the taskforce sees that the company has not been recruiting African-American engineers, it will suggest sending recruiters to historically black colleges. If a company has trouble retaining women, the diversity manager may talk to women at risk of leaving and try to work out arrangements that will keep them on the job. Managers and taskforces monitor quarterly employment data to see if their efforts are paying off. Taskforces may be so widely effective, some diversity managers tell us, because they cause managers from different departments to "buy into" the goal of diversity.

Of the two programs designed to compensate for disadvantages in social capital, networking programs show little direct effect on the share of women and minorities in good jobs. In our analysis of the 1971-2002 data we find that networking programs are followed by significant rises in the odds of white women, and declines in the odds of white men and black men, in management, with no effects on other groups (Dobbin et al., 2007). The negative effect on black men is anticipated by qualitative research showing that whites can develop negative attitudes toward African-American organizing efforts (Carter, 2003; Friedman \& Craig, 2004). Some studies, however, suggest that employee mobilization efforts can shape corporate diversity programs (Briscoe \& Safford, 2008; Dobbin, Kim, \& Kalev, 2011,) and thus networking programs may have indirect effects.

Mentoring programs, by contrast, show strong positive effects on black women, and Hispanic and

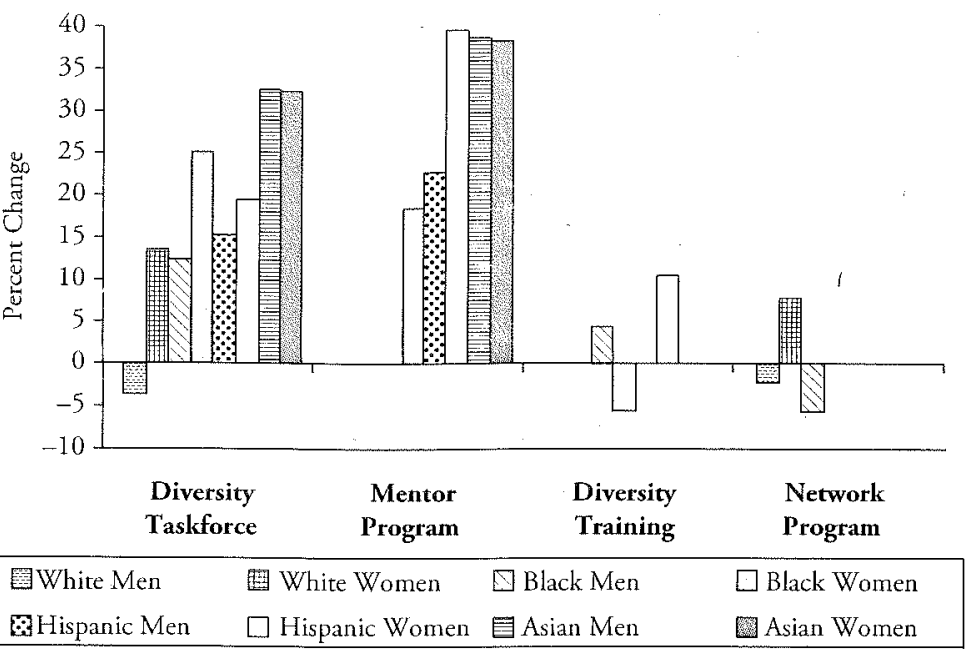

Figure 15.8. Diversity program effects on management diversity.

Asian men and women, in management (Dobbin t al., 2007). In a report prepared for a taskforce of the National Academies of Science, we examined the effects of mentoring programs in differen industries, finding that in industries with significant numbers of college-educated non-managerial workers, who are eligible for promotion to management jobs, mentoring programs led to increases in all seven historically disadvantaged groups in management (white women, and black, Hispanic, and Asian-American men and women) (Dobbin \& Kalev, 2006, p. 3).

Taken together, these findings suggest that personal guidance and support by mentors at work can facilitate career development for workers from all historically disadvantaged groups (Castilla 2005), while the effect of affinity networks is limited to white women. Perhaps networking advantages white women because female networks are more likely than minority networks to include managers, who can serve as mentors. White women make up over 20 percent of managers, whereas no other race by gender group makes up more than 5 percent. Others have looked at related outcomes and found generally posicive effects of mentoring on AfricanAmericans and women. This research is reviewed in Chapter 17 on career development.

\section{The 1990s and beyond: The rise}

\section{of women's issues}

When the Civil Rights Act of 1964 was passed, half of America's leading employers had formal poliies requiring pregnant workers to resign (National ndustrial Conference Board, 1964). Employers routinely barred women from management, refused to hire women with small children, and excluded married women. While women faced barriers similar to those faced by minority men, early corporate equal opportunity programs were focused on racial integration, following the agenda of the civil rights movement of the 1950s. Kennedy's 1961 affirmative action order had not covered sex, but advocates in government, including the President's Commission on the Status of Women created in 1961, championed women's workplace rights, and so sex was covered in the Civil Rights Act of 1964 (Goldin, 1990; Pedriana, 2004, 2006). By 1966 the President's Commission on the Status of Women had spawned 48 state-level commissions, and in that year the National Organization for Women was founded.

In the 1970s, women's rights advocates gained more of a voice and fought for maternity protection and protection against harassment at work (Fretz \& Hayman, 1973; Kelly \& Dobbin 1999; Mansbridge, 1986). Meanwhile, the civil rights focus had fucled both rapid growth in the ranks of personnel managers, which increased sixfold between 1960 and 1980 while the labor force grew by only 50 percent (Jacoby, 1985), and the feminization of its workforce. Women were nearly unknown in personnel as of 1960, but they held half of specialist and manager jobs by 1980 , and 70 percent by the late 1990 s (Roos \& Manley, 1996). Whether due to the legacy of the women's movement, to the growing numbers of women in the workplace, or to the growing presence of women in personnel, women's issues came to assume a larger role in corporate diversity programs. While work-family coordination and sexuat 
harassment prevention are matters that touch men and women alike, women in personnel management carried the torch for new programs.

\section{Work-family programs}

In the early 1970 s, federal law did not require employers to offer maternity leaves, which guaranteed that women could have their jobs back after childbirth, but personnel offices began to create programs in the face of Congressional interest. Forty percent of major employers altered their maternity leave policies between 1972 and 1975 (BNA, 1975). The number of firms offering maternity leave nearly tripled between 1969 and 1978 (Kamerman, Kahn, $\&$ Kingston, 1983). Five states outlawed pregnancy discrimination between 1972 and 1981, but even where pregnancy discrimination was not outlawed personnel managers created maternity leave policie (Ruhm \& Teague, 1997). In Figure 15.9 we compare three states with different legal regimes. Californi had mandated maternity leave, New Jersey offered disability insurance to women on maternity leave, and Virginia had no legal protections. Private-sector employers created new maternity leave programs in all three states.

In 1993, Congress required employers to offer 12 weeks of unpaid leave to new mothers and fathers (Wisensale, 1997). Because personnel experts had already put maternity and medical leaves in place by 1993, the main effect of the law on program adoption was to popularize workplace leave policies for paternity and for the care of sick family members: the prevalence of each kind of progran doubled overnight (Dobbin, 2009).

The women who advocated work-family programs from their positions in human resource departments also promoted flexible work and childcare programs from the $1970 \mathrm{~s}$ (Didato 1977; Packard, 1995; Swart, 1978). Flextime programs typically establish a core set of hour and allow employees to select their own start and end times with supervisory approval (Georgetown University Law Center, 2006; Swart, 1978). B 1978, a handful of leading companies had cre ated flextime programs (Swart, 1978). Congres encouraged part-time career options and flex ible hours through demonstration projects in th federal civil service (Rosenberg, 1980). Human resources experts argued that flextime could be part of a "good faith effort strategy" to show the firm's commitment to equal opportunity for women (Marino, 1980, p. 25).

One study found that flextime programs doubled in popularity to 29 percent between 1977 an 1986 (Fenstein, 1986). A 1984 survey of industry leaders found that 32 percent had created flextim programs since 1980 (BNA, 1986a). Kathleen Christensen's (1989) study for the Conference Board found that by 198746 percent of larg firms surveyed had flextime programs, and another percent were looking into them. A 1986 survey of 1,618 leading companies found that 35 percent had flextime, 34 percent had part-time career programs, 11 percent had job-sharing programs, and 10 percent had work-at-home programs (Kanter, Summers, \& Stein, 1986). A 1994 study showed that 62 percent of leading companies had flexible work hours, 44 percent had job-sharing or part-time programs, and 25 percent had work-athome programs (Miller, 1994).

Our 2002 survey, which includes smaller employers that were less likely to formalize work-family programs, showed that about one third of firms had flextime programs, and nearly as many had part-time-to-full-time transition policies. About one in five had a work-at-home program (Fig. 15.10). lob sharing was still spreading as of 1997 (Rapoport \& Bailyn, 1996). Unlike maternity leave, which was legally mandated by 1994 , Alexible scheduling policies were discretionary. Employees could apply to use these programs, but supervisors had to approve their use (Kelly \& Kalev, 2006).

From the early 1980s, human resources consultants promoted child-care programs, arguing that they could increase employee commitment and decrease turnover while helping employers to demonstrate a "good faith" efforr to foster gender equality (Kossek \& Nichol, 1992). Personnel consultants invented the most popular child-care benefic today, the dependent-care expense account, by building on 1981 legislation designed to encourage onsite child care (Kelly, 2003). Consultants convinced the Internal Revenue Service to allow expense accounts under the law, to extend the tax benefit to workers without access to onsite child care (Kamerman \& Kahn, 1987, pp. 276-277)

Dependent-care expense accounts took off in the mid-1980s, and they appear to have given a boost also to referral services, onsite child care, and vouchers (Solomon, 1988). A 1998 survey found 50 percent of employers offering expense accounts and 9 percent offering onsite child care (Galinsky \& Bond, 1998). Joanne Miller's 1994 survey of leading employers found 19 percent with onsite child care (1994b). By 2002, two thirds of firms in our sample offered dependent-care expense accounts, about a quarter had child-care referral services, and less than one in ten offered onsite child care or vouchers (see Fig. 15.10)

\section{Do work-family programs increase opportunities for women}

\section{and minorities}

There is limited research on the effects of corporate work-family programs on workplace inequality, and most studies use cross-sectional data that make it difficult to establish causality. Studies document employee perceptions that work-family arrangements improve productivity (Eaton, 2003) but may impair workplace attainment (Estes \& Michael, 2005; see Kelly et al., 2008, for a review). Other findings suggest that family leaves

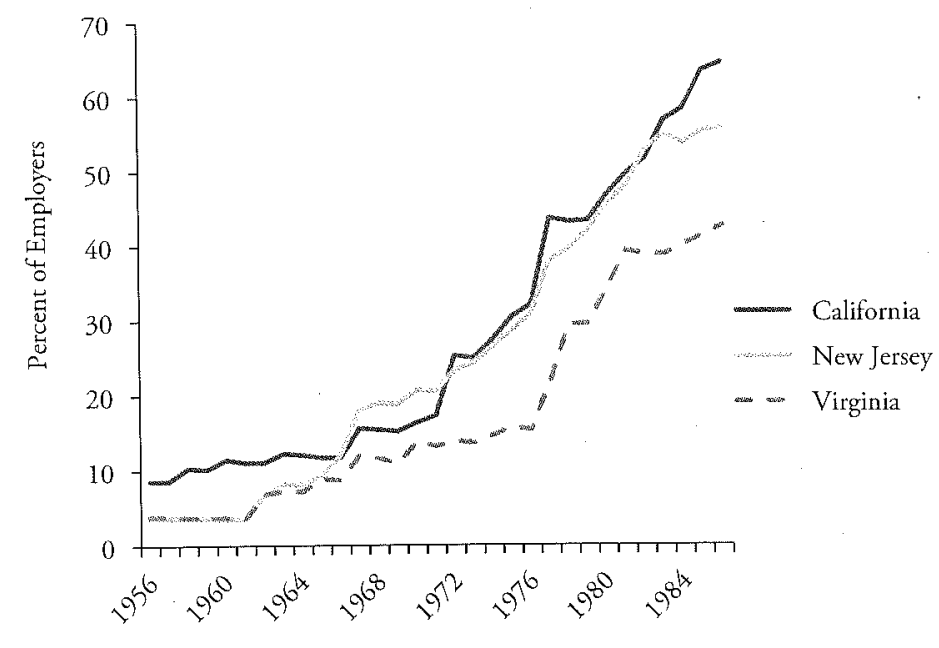

Year

Figure 15.9. Maternity leave by state.

Source: Survey of 279 employers in 1986 (Dobbin et al., 1993).

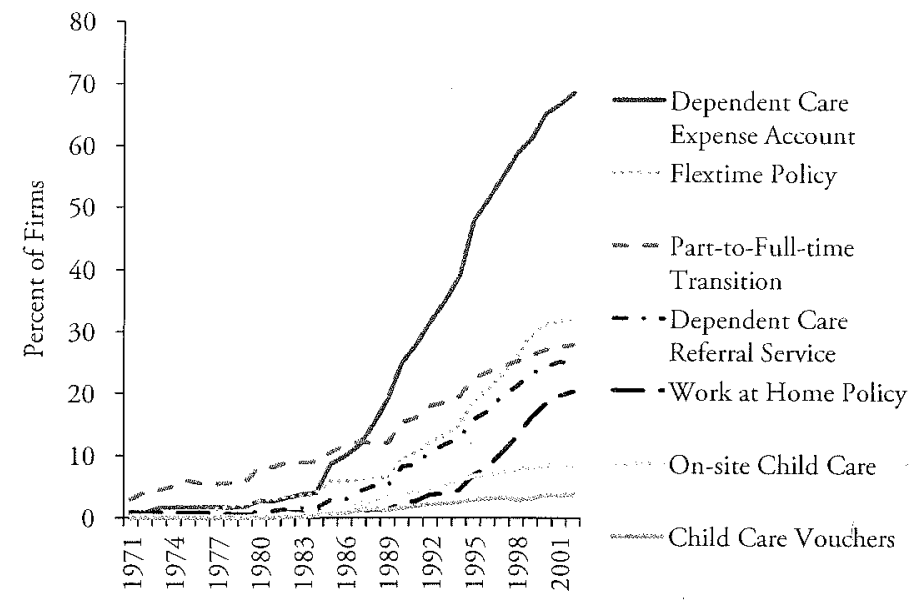

Year

Figure 15.10. Flexible scheduling and child-care programs.

urce: Surveys of 829 employers in 2002 and 389 employers in 1997 (Dobbin \& Kelly 2007; Kalev er al., 2006). 
may reduce discontinuities in women's labor force participation but may lead to the segregation of women in lower-level jobs or in certain departments (Estes \& Glass, 1996; Glass \& Riley, 1998; Waldfogel, 1998). One study shows that users of parental leaves are less frequently promoted than other employees (Judiesch \& Lyness, 1990). This pattern has also been seen in some European countries (Mandel \& Semyonov, 2005).

There is evidence that men pay a higher penalty for using family leave. Allen and Russell (1999) find that men taking parental leaves were less likely to be rewarded than men who eschew leaves and women who take them (see also Stafford \& Sundstrom, 1996; Wayne \& Cordeiro, 2003). These differentials may not show up in aggregate data because leave use by men remains low.

We know even less about the effects of flexible scheduling and child-care programs on women's and men's careers, and little about how the effects of work-family programs vary across racial, ethnic, and occupational groups. Research in this area is discussed in Chapter 20.

\section{Sexual harassment grievance}

\section{systems and training}

As the human resources profession became feminized, it directed attention to the issue of sexual harassment as well. Harassment had not been mentioned in the Civil Rights Act, but feminist law professor Catharine MacKinnon argued that harassment at work should be treated as sex discrimination under Title VII (Saguy, 2003). The courts did not immediately agree, but in 1976 and 1977 three federal courts found that quid pro quo harassment constitutes sex discrimination. The rulings did not outline compliance measures, but personnel experts revived an old standard from the person nel playbook: they proposed law-like procedures to remedy complaints that were designed to appeal to both judges and executives (Spann, 1990, p.57). Grievance procedures, they argued, could intercept harassment complaints and simultaneously telegraph the firm's no-tolerance policy on harassment (Hoyman \& Robinson, 1980, pp. 14-15: Linenberger \& Keaveny, 1981a, 1981b).

Few employers had harassment procedures in place before the federal judicial decisions of 1976 and 1977, but by the time of our 1986 survey, one in five firms had them. The Supreme Court ruled in 1986 that hostile environment harassment was covered by the Civil Rights Act and in dual rulings in 1998 suggested that employers who trained workers in company anti-harassment policies, and offered workers effective grievance mechanisms, might be protected against liability for harassment. Many observers claimed that these decisions moved the court into the territory of making law (Greenhouse, 1998, p. A20). But these practices were already ubiquitous in American firms, thanks to the advocacy of human resources experts (Nation's Business; 1998, p. 15). By 1991, the Wall Street Journal reported, harassment training had nearly saturated the Fortune 500 (Lublin, 1991). Glamour magazine reported that 86 percent of the Fortune 500 had training in place by the end of 1992 (Trost,
1992). As Figure 15.11 shows, according to the 997 survey Dobbin and Kelly (2007) conducted, nadvance of the dual 1998 Supreme Court rulings, sexual harassment grievance procedures and training were widespread.

\section{Dogrievance procedures and}

\section{training tame harassment?}

While the Court accepted the theory that anti-harassment training programs and grievance procedures can prevent harassment and resolve complaints, there is little evidence to that effect. Legal scholar Susan Bisom-Rapp (2001) reviews the seholarly studies of anti-harassment training and finds no evidence that it actually reduces the incidence of harassment. As for grievance procedures, Lauren Edelman and colleagues (Edelman et al., 1999) look at time-series data from a national sample of firms and find no evidence that corporate grievance procedures reduce the incidence of harassment claims made to the government. Of course it may be that sexual harassment grievance procedures and training raise awareness about harassment and hence increase the number of complaints. In an analysis of evidence from workplace ethnographies, Lopez, Hodson, and Roscigno (2009) find tha grievance mechanisms reduce sexual harassment but have no effect on general harassmenc. All in all, the jury is still out on whether anti-harassment training or harassment grievance procedures actually reduce the incidence of harassment.

\section{Conclusion}

Over the years personnel managers have put into place a series of different equal opportunity and diversity management programs. These measures were initially stimulated by the civil rights movement and John F. Kennedy's 1961 order requiring federal contractors to take "affirmative action" to end discrimination. Many of the strategies personnel managers developed came from their profession's kitbag. Each wave of measures redefined discrimination in the American mind.

In the 1960s, managers created corporate nondiscrimination policies. They expanded on traditional recruitment programs for skilled workers, now targeting historically black colleges and urban high schools. They built on conventional skill and management training practices, establishing programs designed for blacks and women. In the process they defined nondiscrimination as a matter of forbidding managerial bias and righting past wrongs through recruitment and training.
When Washington strengthened civil rights regulations in the early 1970 s, personnel experts championed new equal opportunity programs built on the foundation of classic personnel administration. New practices were designed to bureaucratize hiring and promotion and thereby prevenc bias: test validation, salary classification, job posting, and performance evaluations. These policies depicted structural flaws in the hiring and promotion process as the source of employment discrimination, and redesigned bureaucratic hiring and 'promotion systems as the remedy. These changes were to prevent managerial bias from tainting hiring and advancement, and they defined the formalization of personnel practices as the best way to prevent discrimination.

When Ronald Reagan moved into the White House in 1981 and threatened to turn the clock back on civil rights regulations, personnel experts fought back by developing business arguments for these programs. They dropped the language of legal compliance for a language of "diversity management." This language redefined discrimination as the result of managerial ignorance, to be addressed through training, and inequality as a result of the propensity of identity group members to stick together, to be addressed through mentoring and networking programs.

As the human resources profession became feminized, between 1970 and 1990, diversity programs became more oriented to women's issues. Work-family programs received renewed attention and spread broadly. New programs were put into place to fight sexual harassment at work. These innovations defined sex inequality at work as a consequence of conflicts between gender roles and work roles.

Research on the effects of these programs is ongoing, but we know that a number of them did little to promote gender and racial diversity. The innovations of the 1960s and 1970s appear to have had mixed effects. Targeted recruitment efforts have brought more women and minorities into the workplace, and skill and management training programs helped women and minorities to move up where they had access to those programs, but they were often denied access. Firms that hired full-time diversiry officers, or created special departments, saw increases in diversity. Yet evidence to date suggests that bureaucratic hiring and promotion systems may have done more harm than good, institutionalizing patterns of inequality rather than challenging them. The diversity management movement of the 
1980s popularized some ineffective diversity initiatives, such as diversiry training and diversity performance reviews, and spawned some quite effective initiatives, such as diversity taskforces and mentoring programs. When it comes to work-family programs, extant research suggests that parental leaves have increased both participation of women in the workforce and job segregation, but we are still in the dark regarding the effects of flexible work schedules and child-care arrangements.

Our survey of research on the effects of these programs leads to several conclusions about the features of successful programs. The first is that corporations that put managers in charge of promoting diversity typically see results. Making managers a part of the solution, by appointing a full-time diversity manager, creating an interdepartmental taskforce, or assigning managers as mentors, helps to promote diversity. Moreover, diversity programs that otherwise have null or negative effects work better in the context of these practices. Similarly, regulatory oversight has been shown to improve the effects of certain diversity programs (Kalev et al., 2006). The second conclusion is that innovations designed to quash managerial bias have been broadly ineffective. Bureaucratic practices designed to eliminate managerial discretion from the hiring and promotion process have not led to increases in diversity; nor have diversity training programs designed to make managers aware of their own unconscious biases; neither have diversity performance evaluations that give managers feedback and career incentives to improve diversity. All three innovations point to managers as the problem to be solved, rather than as the source of the solution. All three are designed to change individual managers behavior. The evidence suggests that this approach can have modest positive effects in the presence of managerial oversight of diversity efforts, but that it typically fails.

Research on diversity management and the remediation of workplace inequality is in its infancy. We still have understand little about how diversity programs influence workforce composition. Next we suggest several lines of future inquiry to deepen the field's understanding of corporate diversity efforts.

\section{$A$ better understanding of failure}

Why do certain innovations consistently fail to bring about change? We need better theories of what makes broad classes of managerial innovations effective, as proponents of evidence-based management have pointed out (Pfeffer \& Sutton 2005). To begin with, we need better data on th mechanisms by which innovations shape behavio Two specific domains of future research surface On the one hand, we need to better understand why bureaucratic hiring and promotion system designed to standardize personnel decisions hav failed to promote diversity. Is it, as feminists argue (Acker, 1990), because bureaucracy formalizes tradi tional bases of exclusion by, for instance, establis ing length-of-service requirements for management jobs that exclude mothers who have taken time off for childbirth? Is it because performance evaluations and salary classification systems are used selectively. by managers in making promotions and assigning wages (Nelson \& Bridges, 1999; Roscigno, 2007)? Is it because bureaucratic procedures create an appearance of equality and fairness, which has the effect, as Castilla and Benard (2010) suggest, of dampening managers' scrutiny of their own behavior? A second set of questions is suggested by the failure of diversity training and diversity performance evaluations to foster workforce diversity. Do these programs lead to adverse reactions from managers? Do they somehow reduce the motivation of managers to hire women and minorities? Organizational theory largely treats failure to change as an instance of decoupling, wherein formal structures are ignored in the everyday practice of the organization. As this list of questions suggests, failure may be caused by any number of processes other than decoupling.

\section{A better understanding of success}

Why do certain classes of innovations consistently succeed in bringing about change? We have noted that managerial and regulatory oversight of diversity efforts fosters success, but we know little about the underlying mechanisms. For example, do managers with hiring and promotion authority invest additional cognitive effort in processing data when they know they may need to explain their decisions (Lerner \& Tetlock, 1999)? Does assigning responsibility simply ensure that someone takes charge of the task? Or does cognitive dissonance lead to greater commitment among managers assigned responsibility for diversity? And what are the mechanisms that transform the commitment of diversity managers, and taskforces, into substantive organizational change? Understanding the mechanisms underlying positive effects promises to help us to design better diversity programs, and tweak those already in place.

\section{A broader understanding of diversity}

How do diversity efforts affect the age distribuion of the workforce, the utilization of disabled workers, and workforce composition by sexual orientation and immigration status? Does the effect of diversity effort vary at the intersection of social categories? Most research on diversity program effects focuses on gender, race, or ethnicity. We need more theory and research on other dimensions of disadvantage, as well as on the intersection of social categories. The findings we have outlined suggest some open questions concerning the intersection of race and gender. Why is it that black men see negative effects from nerworking programs whil white women see positive effects? Why does diversity training appear to help black men but hur black women? It is possible that differences in rela rional dynamics and in the content of gender and racial stereotypes (Browne \& Misra, 2003; Moss \& Tilly, 2001; Roscigno, 2007) lead to different program outcomes across the intersection of gender and race. We expect there are unplumbed program effects across other intersections as well. Thus, sal ary classification systems that emphasize skills ove tenure, for instance, may advantage women with careers interrupted by maternity, but disadvantage older men with greater seniority. The intersection of race and immigration status is also unexplored. Thus, criminal record checks may expand hiring of blacks by countering the employer tendency to assume that all black men have criminal records (Holzer, Raphael, \& Stoll, 2006), but do they also deter undocumented immigrants from applying for jobs

\section{A better understanding of context}

How do organizations moderate wider contextual changes that influence workforce diversity? Most studies of corporate diversity efforts examine them in isolation from broader social changes, but many other changes in the organizational environmental have occurred in recent decades. We know, for instance, that elements of the new high-performance management paradigm have driven increases in diversity, even though they were not designed to (Kalev, 2009). Decades of studles suggest that minorities lose a disproportionate number of jobs in recessions (Wilson \& Branch McBrier, 2005), but we know little about the effects of the downsizing and outsourcing fads on workforce composition and on corporate diversity efforts (Dencker, 2008).
Many firms have joined the performance-based compensation bandwagon, but we have scant knowledge of whether this trend has affected workforce composition. The literature on tokenism suggests that minorities who reach the top face extra scrutiny and stress (Kanter, 1977), but we do not know whether women and minorities on boards of directors stimulate growth in diversity in the lower ranks. We know that legal immigrants sometimes face labor market discrimination, but have raids on factories employing illegal immigrants had a further chilling effect on hires of legal immigrants? And has the "corporate social responsibility" movement affected corporate diversity efforts and workforce composition?

\section{$A$ better understanding of the bottom line}

In the civil rights era, the great promise of equal opportunity programs was that they could increase social justice in America. The great promise of the diversity management movement today is that workforce diversity can also contribute to the corporate bottom line. But as yet, research has not produced clear evidence of the effect of diversity on performance. Cross-sectional studies suggest that diversity is positively correlated with a number of performance measures (Herring, 2009). But early studies showing a positive correlation between corporate board diversity and performance (Catalyst, 2007) were thrown into doubt by sophisticated time-series studies (Adams \& Ferreira, 2009). Putting together the kind of rich longitudinal data required for exploring this question is a challenge, but several groups of sociologists are now at work on that.

All of these areas for future research require richer data from a variery of sources. For instance, the challenge of studying the effects of diversity policies and programs on workforce characteristics beyond sex, race, and ethnicity is substantial, for the most revealing studies use federal data (Kalev et al., 2006; Leonard, 1990), and the federal government does not collect systematic data on age, immigration status, disability, or sexual orientation. Perhaps the best hope for obtaining time-series data ar the firm level lies in career data collected by firms themselves for internal use, such as those used by Fernandez (2001) and Castilla and Benard (2010).

To achieve a fuller understanding of program effects on careers, the ideal dataset would match time-series data from a large number of employers with data on individual employees. A longitudinal version of the National Organizational Survey 
(Kalleberg, Knoke, Marsde, \& Spaeth, 1996), which surveys individuals and then turns to their employers, would help us to understand how program effects vary across employee characteristics. Do networking programs lead to declines in black men in management by increasing quit rates, by facilitating promotions for white women that leave black men behind in the labor queue, or by some other mechanism? Perhaps the solution is to merge existing longitudinal data on individuals, from a source such as the National Longitudinal Survey of Youth, with retrospective data from the firms that employed them. Case studies, ethnographic research, and depth interviews can help us to understand how inequality is reproduced, or challenged, on the ground in firms (Kellogg, 2009; Kelly, Moen, \& Tranby, 2011). Such data can shed light on the real-world experiences of workers, and on the relational dynamics that mediate the implementation of diversity program innovations.

\section{References}

bbott, A. D. (1994). Review by Harrison White of "Identity and Control: A Structural Theory of Social Action." Socit Forces, 73, 895-901

Acker, J. (1990). Hierarchies, jobs, bodies: a theory of gendered organizations. Gender \& Society, 4(2), 139-158.

Ackerman, R. (1973). How companies respond to social demands. Harvard Business Review, 5I(1), 88-98.

Adams, R. B., \& Ferreira, D. (2009). Women in the boardroom and their impact on governance and performance. Journal of Findncial Economics, 94(2), 291-309.

Allen, T. D., \& Russell, J. E. A. (1999). Parental leave of absence: Some not so family friendly implications. Journal of Applied Social Psychology, 29, 166-191.

Anderson, B. E. (1996). The ebb and flow of enforcing Executive Order 11246. American Economic Review, 86(2), 298-301.

Anderson, C. D., \& Tomaskovic-Devey, D. D. (1995). Patriarchal pressures: an exploration of organizational processes tha exacerbate and erode gender earnings inequality. Work and Occupattions, 22(3), 328-356.

Appelbaum, E., \& Berg, P. (2001). High-performance work systems and labor market structures. In Ivar Berg \& Arne L. Kalleberg (Eds.), Sourcebook of labor mutrkets: Evolving L. Kalleberg (Eds.), Sourcebook of labor mutrkets: Evolving
structures of processes (pp. 271-293). New York: Kluwer structures of proceses

Auster, E. R., \& Drazin, R. (1988). Sex inequality at higher levels in the hierarchy: An intraorganizational perspective. Sociological Inquiry, 58, 216-227

Baron, J. N., \& Bielby, W. T. (1986). The proliferation of job titles in organizations. Adrninistrative Science Quarterly, 31 $561-586$.

Baron, J. N., Hannan, M. T., Hsu, G., \& Koçak, Ö. (2007). In the company of women: gender inequality and the logic of bureaucracy in start up frms. Work dod Occuputions $34(1)$ bureavic

Baron, J. N., Jennings, P. D., \& Dobbin, F. (1988). Mission control? The development of personnel systems in US. industry. American Sociological Review, 53, 497-514.
Baron, J. N., \& Pfeffer, J. (1994). The social psychology o organizations and inequality. Social Psychology Quartert,

Bartol, K. M. (1999). Gender influences on performance evaluation. In Gary N. Powell (Ed.), Handbook of gender and work (pp. 165-178). Thousand Oaks, CA: Sage.

Belz, H. (1991). Equality transformed: A quarter affirmative action. Brunswick, NJ: Transaction.

Bielby, W. T. (2000). Minimizing workplace gender and racial bias. Contemporary Sociology, 29(2), 120-129.

Bills, D. B., \& Hodson, R. (2007). Worker training: a revie critique, and extension. Research in Social Stratificaition and itity, 25, 258-272.

Bisom-Rapp, S. (1999). Bulletproofing the workplace: symbol and substance in employment discrimination law practic Florida State University Law Revieu, 26, 959-1049.

Bisom-Rapp, S. (2001). Fixing watches with sledgehammers: the questionable embrace of employee sexual harassment training by the legal profession. University of Arkansus Little Rock Law Revieu, 24, 147-168.

Blair-Loy, M. (2001). It's not just what you know, it's who you know: technical knowledge, rainmaking, and gender among finan executives. Resedrch in the Sociology of Work, 10, 51-83.

Blumrosen, A. W. (1993). Modern law: The law tratnsmission system and equal employment opportunity. Madison, WI: University of Wisconsin Press.

Boyle, M. B. (1973). Equal opportunity for women is smart business. Harvard Business Revieu, 51(3), 85-95.

Braestrup, P. (1961, June 5), U.S. unit presses for job equality. New York Times, p. 22.

Briscoe, F., \& Safford, S. (2008). The Nixon in China effec activism, imitation, and the institutionalization contentious practices. Administrative Science Quarterly, 53, $460-491$

Browne, I., \& Misra, J. (2003). The intersection of gender and race in labor markets. Annual Review of Sociology, 29 $487-513$

Bureau of the Census (1975). Historical statistics of the Uritied States: Colonial times to 1970. Washington, DC: U.S Government Printing Office.

Bureau of National Affairs (1967). A current look at: (1) The Negro and Title VII (2) Sex and Title VII (No. 82). Washington DC: Burcau of National Affairs.

Bureau of National Affairs (1976). Equal employment opportunity: Proorams and results (PPF Survey No. 112). Washington, DC: Bureau of National Affairs.

Bureau of National Affairs (1975). Paid leatve and leave of absence policies (Personnel Policies Forum Survey No. 111). Washington, DC: Bureau of National Affairs.

Bureau of National Affairs (1986a). Work and family: a chatnging agenda. Washington, DC: Bureau of National Affairs.

Bureau of National Affairs (1986b). Affirmative action today a legal and practical analysis. Washington, DC: Bureau of

Burke, R. J., \& McKeen, C. A. (1997). Not every managerial woman who makes it has a mentor. Women in Managemem Review, 12(4), 136-139.

Burt, R. S. (1998). The gender of social capital. Rationality and Society, 10(1), 5-46.

Campbell, J. T. (1973). Tests are valid for minority groups too. Public Personnel Management, 2, 70-73.

Carter, J. (2003). Ethnicity, exclusion and the workplace. London: Palgrave Macmillan Press.
Castilla, E. J. (2005). Social nerworks and employee performance in a call center. American Journal of Sociologh 110(5), $1243-1284$

Castilla, E. J., \& Benard, S. (2010). The purudox of meritocracy: an experimental approach to study why merit-based perfornatnce systems fail. Paper presented at the annual meeting of the American Sociological Association, August, Boston, 55, $543-576$

Catalyst (2007). The bottom line: Corporate performance and women's representation on bourds. New York: Catalyss.

Chayes, A. (1974). Make your EEO program court-proof.

Chen, A. S. (2009). The fifth freedom: Jobs, politics, and civil rights in the United States, 1941-72. Princeton, NJ: Princeton University Press.

Christensen, K. E. (1989). Flexible staffing and scheduling in U.S. corporations. New York: The Conference Board.

onference Board (1992). In diversity is strength: Capitalizing on the new work force. 75 th Anniversary Symposia Series. Report Number 994. New York.

costain, A. N. (1992). Inviting women's rebellion: A political process interpretution of the women's movement. Baltimore, MD: Johns Hopkins University Press.

coss, E. Y. (1996). Letters to the editor: Managing diversiry. Harvard Business Review, 74(6), 177-178.

unningham, R. M. (1936). Some problems in measuring performance of industrial salesmen. Harvutrd Business Review, I4(1), 98-113.

anovitch, S. (1990). Interview conducted December 27, 1990, as part of an oral history project to commemorate the EEOC's 25th Anniversary. Retrieved from http://www.utoronto.ca/ wjudaism/contemporary/articles/history_Eeoc.hrm

encker, J. C. (2008). Corporate restructuring and sex differences in managerial promotion. American Sociological Revieu, 73, 455-476.

Detefson, R. R. (1991). Civil rights under Reagann. San Francisco: ICS Press.

Didato, S. (1977, May 22). Problems cut by Plexitime. Washington Post, p. D6.

Diprete, T. (1989). The bureaucrutic labor matrket: The case of the federal civil service. New York: Plenum.

DiPrete, T. A., \& Soule, W. T. (1988). Gender and promotion in segmented job ladder systems. Americant Sociologicat Revieu $53(1), 26-40$

Dobbin, F. (2009). Inventing equal opportunity. Princeton, NJ: Princeton Universiry Press

Dobbin, F., Edelman, L. B., Meyer, J. W., Scotr, W. R., \& Swidler, A. (1988). The expansion of due process in organizations. In Lynne G. Zucker (Ed.), Institutional patterns and organizations Culture and enuironment (pp. 71-100). Cambridge, MA. Ballinger.

bbin, F., \& Kalev, A. (2006). Diversity manutgement and munagerial diversity. Special report to the National Academies Committec on Women in Academic Science and Engineering.

obbin, F, Kalev, A., \& Kelly, E. (2007). Diversity management in corporate America. Contexts, 6(4), 21-28.

bbin, F., Kim, S., \& Kalev, A. (2011). You can't always get what you need: why diverse firms adopt diversity programs. American Sociological Review, 76(3), 386-411.

bbin, F., \& Kelly, E. (2007). How to stop harassment: the professional construction of legal compliance in organizations. American Journat of Sociology, 112(4), 1203-1243.
Dobbin, F., \& Sutton, J. R. (1998). The strength of a weak state: the employment rights revolution and the rise of human resources management divisions. American Jourudl of Sociology, 104(2), 441-476

Dobbin, F., Sutton, J. R., Meyer, J. W., \& Scott, W. R. (1993). Equal opportunity law and the construction of internal labor markets. American Journal of Sociology, 99(2), 396-427.

Drum, R. S. (1960). Performance evaluation. Personnel Journal $38(2), 338-340$

Dugan, R. D. (1966). Current problems in test performance of job applicants: II. Personnel Psychology, 19(1), 18-24

DuRivage, V. (1985). The OFCCP under the Reagan administration: affirmative action in retreat. Labor Law Journal, 36, 360-368.

Eaton, S. (2003). If you can use them: Flexibility policies, organizational commitment and perceived performance. Industrial Relations, 42, 145-167.

Edelman, L. B. (1992). Legal ambiguity and symbolic structures: organizational mediation of civil rights law. American fourzal of Sociology, 97, 1531-1576.

Edelman, L. B. (1990). Legal environments and organizational governance: the expansion of due process in the American workplace. American Journal of Sociology, 95, 1401-1440.

Edelman, L. B. (2002). Legality and the endogeneity of law. In Robert A. Kagan, Martin Krygier, \& Kenneth I. Winston (Eds.), Legality and community: on the intellectual legacy of Philip Selznick (pp. 187-203). Lanham, MD: Rowman and Litrlefield.

Edelman, L. B., Fuller, S. R., \& Mara-Drita, I. (2001). Diversity rhetoric and the managerialization of the law. American Jourral of Sociology, 106(6), 1589-1641.

Edelman, L. B., \& Petterson, S. M. (1999). Symbols and substance in organizations' response to civil rights law. Research in Social Stratification and Mobility, 17, 107-135.

Edelman, L. B., Uggen, C., \& Erlanger, H. S. (1999). The endogeneity of legal regulation: grievance procedures as rational mych. American Journal of Sociology, 105, 406-454.

EOC (1998). Best practices of private sector employers. Washington, DC: Equal Employment Opportunity Commission. Retrieved April 19, 2004 (http://www.eeoc. gov/abouteeoc/task_reporrs/practice.hrml).

Elvira, M. M., \& Graham, M. E. (2002). Not just a formality: pay system formalization and sex-related earnings effects. Organization Science, 13(6), 601-618

Elvira, M. M., \& Town, R. J. (2001). The effects of race and worker productivity on performance evaluations Indusitrial Relations, 40, 571-590.

Elvira, M. M., \& Zatzick, C. D. (2002). Who's displaced first? The role of race in layoff decisions. Industrial Relations, $41(2), 329-361$

Esen, E. (2005). Workplace diversity practices survey report. Alexandria, VA: Society for Human Resource Management.

Estes, S. B., \& Glass, J. (1996). Job changes following childbirth: are women trading compensation for family-respond

Estes, S. B., \& Michael, J. (2005). Work-family policies and gender inequality at work. Sloan Work Fumily Research Network Encyclopedia

Ewick, P., \& Silbey, S. S. (1998). The common place of law: stories from everyddy life. Chicago: University of Chicago Press.

Fehn, B. (1993). "Chickens come home to roost": Industrial reorganization, seniority, and gender conflict in the United 
Packinghouse Workers of America, 1956-1966. Labor History, 34(2\&3), 324-341

Fenstein, S. (1986, June 10). Labor Letter. Wall Street Journal, p. 1.

Ferguson, K. E. (1984). The feminist case against bureacracy. Philadelphia: Temple University Press.

Fernandez, R. M. (2001). Skill-biased technological change and wage inequality: evidence from plant retooling. American Journal of Sociology, 107(2), 273-320.

Foulkes, F. K., \& Morgan, H. M. (1977). Organizing and staffing the personnel function. Harvard Business Review $55(3), 142-177$

Fox, J. R. (1981). Breaking the regulatory deadlock. Harvard Business Review, 59(5), 97-120

Fretz, C. F., \& Hayman, J. (1973, Seprember-October). Progress for women? Men are still more equal. Hatrvard Business Revieu, 133-142.

Friedman, R. A., \& Craig, K. M. (2004). Predicting, joining and participating in minority employee network groups. Industrial Relations, 43(4), 793-816.

Froehlich, H., \& Hawver, D. (1974). Compliance spinoff: better personnel systems. Personnel, 51(1), 62-69.

Fulmer, R. M., \& Fulmer, W. E. (1974). Providing equal opportunities for promotion. Personnel Journal, 53, 491-497.

Galinsky, E., \& Bond, J. T. (1998). The 1998 business work-life study. New York: Families and Work Institute.

Gant, S. B., \& Gentile, M. C. (1995, March 13), Kurt Landgraf and Du Pont Merck Pharmaceutical Company. Harvard Business School Press.

Gavin, J. F., \& Toole, D. L. (1973). Validity of aptitude test for the "hardcore unemployed." Personnel Psychology, 26, $139-146$

Georgetown University Law Center (2006, spring). Workplace flexibility 2010 legal memo: The Federal Employees Flexible and Compressed Work Schedules.Act (FEFCWA). Georgetown and Compressed Work Sche

Giblin, E., \& Ornati, O. (1974). A total approach to EEO compliance. Personinel, 51(5), 32-43.

Glass Ceiling Commission (1995). A solid investment: making full use of our nation's human capital. Washington, DC: U.S Department of Labor Glass Ceiling Commission.

Glass, J. L., \& Riley, L. (1998). Family-responsive policies an employee retention following childbirth. Social Forces, 76(4) 1401-1435.

Goldin, C. (1990). Understanding the gender gatp: an economic bistory of American women. New York: Oxford University Press.

Gordon, H. L. (2000) Cobb County Oral Hisrory Series No. 75. Interview with Hugh L. Gordon conducted by Joyce A. Patterson. Kennesaw State University.

Gorham, W. A. (1972). New answers on employment tests. Civil Service Journal, 13, 8-12.

Graham, H. D. (1990). The civil rights era: origins and developmen of national policy 1960-1972. New York: Oxford University Press.

Granovetter, M. (1974). Getting a job: a study of contracts and careers. Chicago: University of Chicago Press.

Greenhouse, L. (1998, April 23). Sex harassment seems to puzzle Supreme Court. New York Times, pp. A1-A20.

Grove, G. (1965, September 18). When a "No. 2" applies for a job. New York Times, p. SM32

Guetzkow, H. (1965). Communications in organizations. In James G. March (Ed.), Handbook of orgatnizations (pp. 534-573) Chicago: Rand McNally. (1974). Race and sex as determinants of ratings by potental
(a) . employers in a simulated work-sampling task. Journat of Applied Psychology, 59(6), 705-712.

Harrison, C. (1988). On account of sex: the politics of women issues 1945-1968. Berkeley, CA: University of Californi Press.

Harvard Law Review (1989). Rethinking Weber: the business response to affirmative action. Harvard Law Revieu, 102 658-671.

Herring, C. (2009). Does diversity pay? Race, gender and the business case for diversity. American Sociological Revitew,

Hight, J. E. (1998). Young worker participation in post-school education and training. Monthly Labor Review, 12l, 14-21. Holzer, H. J., \& Neumark, D. (2000). What does affirmative action do? International Labor Relations Revieu, 53 240-271.

Holzer, H. J., Raphael, S., \& Stoll, M. (2006). Perceived criminality, criminal background checks and the racial hiring practices of employers. Journal of Law and Economics, 49, $451-480$.

Hough, L. M., \& Oswald, F. L. (2000). Looking toward the furure-remembering the past. Anrual Review of Psycholugy 51, 631-664.

Hoyman, M., \& Robinson, R. (1980). Interpreting the new sexual harassment guidelines. Personnel Journat 43(4), 996-1000

Huffman, M. L., \& Velasco, S. C. (1997). When more is less: sex composition, organizations, and earning in U.S. firms. Work and Occupations, 24(2), 214-244.

Ibarra, H. (1992). Homophily and differential returns: sex differences in network structure and access in an advertising firm. Administrative Science Quatrerly, 34, 422-447.

Ibarra, H. (1995). Race, opportunity and diversity of social circles in managerial networks. Actdemy of Management Journal, 38, 673-703.

Ichniowski, C. (1983). Have angels done more: the steel-industry consent decree. Industrial and Labor Relations Revieu, 36(2), 182-198.

Jacoby, S. M. (1985). Employing bureaucrutcy: managers, unions and the transformation of work in American industry, 19001945. New York: Columbia University Press.

Johns, H., \& Moser, H. R. (1989). Where has EEO taken personnel policies? Personnel, 66(9), 63-66.

Jordan, K. (1998). Diversity training in the workplace today: a status report. Journal of Career Pldaning and Employwer 59(1), 46-51.

Judiesch, M. K., \& Lyness, K. S. (1990), Left behind? The impac of leaves of absence on managers' career success. Acidemy af Mandgement Journal, 42, 641-651.

Kalev, A. (2009). Cracking the glass cages? Restructuring and ascriptive inequality at work. American Journal of Sociolog. $114(6), 1591-1643$

Kalev, A., \& Dobbin, F. (2006). Enforcement of civil right law in private workplaces: the effects of compliance review and lawsuits over time. Law and Social Inquiry, 31(4) 855-879.

Kalev, A., Dobbin, F., \& Kelly, E. (2006). Best practices or best guesses? Diversity management and the remediation inequality. American Sociological Revieu, 71, 589-617.

Kalleberg, A. L., Knoke, D., Marsden, P. V., \& Spaeth, J.L (1996). Organizations in America: andlyzing their structure atd human
Publications. employes and a changing labor force. New York: Columbia University Press.

amerman, S. B., Kahn, A. J., \& Kingston, P. (1983). Mutternity policies

M. (1977). Men and women of the corporation (2nd ed.). New York: Basic Books.

Gnter, R. M., Summers, D. V., \& Stein, B. A. (1986). The future of workplace alternatives. Metrugement Review, 75(7), 30-34 kellogg, K. C. (2009). Operating room: relational spaces and microinsticutional change in surgery. American Journal of Sociology, $115(3), 657-711$

elly, E., \& Dobbin, F. (1999). Civil rights law at work: sex discrimination and the rise of maternity leave policies. American fournat of Sociology, 105, 455-492.

elly, E., \& Kalcy, A. (2006). Managing flexible work arrangements in U.S. organizations: formalized discretion or "a right to ask." Socio-Economic Revieu, 4(3), 379-416.

kelly; E. A. (2003). The strange history of employer-sponsored childcare: interested actors, uncertaincy, and the transformation of law in organizational fields. American Journal of Sociology, 109(3), 606-649.

elly, E. A., \& Dobbin, F. (1998). How affirmative action became diversiry management. American Behatioral Scientis $1,960-984$

Kelly, E. L., Moen, P., \& Tranby, E. (2011). Changing workplaces to reduce work-family conflict: schedule control in a white-collar organization. American Sociological Reviem $76,265-290$.

Kelly, E. L., Ellen E. K., Hammer, L., Durham, M., Bray J. Chermack, K., \& Murphy L. 2008. "Gerting There from Here: Research on the Effects of Work- Family Initiarives on Work-Family Conflict and Business Outcomes." Acudermy of Management Amnals, 2 (1), $305-340$

Knoke, D., \& Ishio, Y. (1998). The gender gap in company job training. Work and Occuputions, 25(2), 141

Jochan, T. A., \& Cappelli, P. (1984). The transformation of the industrial relations and personnel function. In Paul Osterman (Ed), Interual labor miarkets (pp. 133-162). Cambridge, MA: MIT Press.

onrad, A. M., \& Linnehan, F. (1995). Formalized HRM structures - coordinating equal-employment opportunity or concealing organizational practices. Academy of Mantgement Journal, 38(3), 787-820.

ossek, E. E., \& Lobel, S. A. (1995). Manatging diversity: humzan resource strategies for transforming the workplitce. Cambridge, MA: Blackwell.

ossek, E. E., \& Nichol, V. (1992). The effects of on-site child care on employee attitudes and performance. Personn Pyychology, 45, 489-509.

aiger, K., \& Ford, J. K. (1985). A meta-analysis of ratee race effects in performance ratings. Journal of Applied Psycholog $70,56-65$.

Kraiger, K., Ford, J. K., \& Salas, E. (1993). Application of cognitive, skill-based, and affective theories of learning outcomes to new methods of training evaluation. Journal of Applied Psychology, 78, 311-328.

Kawiec, K. D. (2003). Cosmetic compliance and the failure of negotiated governance. Wisshington Univiversity Law Qututerly, $81(2), 487-544$.
Kulik, C. T., \& Roberson, L. (2008). Common goals and golden oppornnitives. and organizational settings. Academy of Management Learning and Education, 7(3), 309-331.

Lawrence, P. R., \& Lorsch, J. W. (1967). Differentiation and integration in complex organizations. Administrative Science Quarterly, 12(1), 1-47.

Leach, J., George, B., Jackson, T., \& LaBella, A. (1995). A practical guide to working with diversity: the process, the tools. the resources. New York: AMACOM (Amererican Management Association).

Leonard, J. S. (1990). The impact of affirmative action regulation and equal employment opportunity law on black employment. Journal of Economic Perspectives, 4(4), 47-63.

Leonard, J. S. (1989). Women and affirmative action. Journal of Economic Perspectives, 3(1), 61-75.

Lerner, J. S., \& Tetlock, P. E. (1999). Accounting for the effects of accountability. Pyschological Bulletin, 125(2), 255-275.

Lieberman, R. (2005). Shaping ruce policy: The United States in crmparative perspective. Princeton, NJ: Princeton University

Lieberman, R. C. (1998). Race and state in the United States, Great Britain and Fiunce: employment discrimination policy in comparative perspective. Paper presented at the Annual Meeting of the American Political Science Association.

ieberman, R. C. (2002). Weak state, scrong policy: paradoxes of race policy in the United States, Great Britain, and France. Studies in American Political Development, 16, 138-161.

Linenberger, P., \& Keaveny, T. J. (1981a). Sexual harassment: the employer's legal obligations. Personneh, 58(6), 60-68.

Linenberger, P., \& Keaveny, T. J. (1981b). Sexual harassment in employment. Human Resource Matnagement, 20(1), 11-17.

Lopez Jr., F. M. (1966). Current problems in test performance of job applicants; I. Personnel Psychology, 19(1), 10-18.

Lopez, S. H., Hodson, R., \& Roscigno, V. (2009). Power, status and abuse at work: general and sexual harassment compared. Sociological Quatrterly, 50, 3-27.

Lublin, J. S. (1991, December 2). Sexual harassment is topping agenda in many executive education programs. Wall Street Journal.

Lunding, F. S., Clements, C. E., \& Perkins, D. S. (1979). Everyone who makes it has a mentor. Harvard Business Review, 56(3), 89-101.

Lynch, F. R. (1997). The diversity machine: the drive to change the white male workplace. New York: Free Press.

Lynch, L. M., \& Black, S. E. (1998). Beyond the incidence of employer-provided training. Industrial \& Lator Relations Review, 52(1), 64 .

MacDonald, H. (1993, July 5). Cashing in on affirmative action: the diversity industry. New Republic, 209, 22-25.

Mandel, H., \& Sernyonov, M. (2005). Family policies, wage structures, and gender gaps: sources of earning inequality in 20 countries. American Sociological Review, 43, 949-967.

Mansbridge, J. J. (1986). Why we lost the ERA. Chicago: University of Chicago Press.

Marino, K. (1980). Conducting an internal compliance review of affirmative action. Personuel, 57(2), 24-34.

Mattison, E. G. (1965). Integrating the work force in Southern industry. In Herbert R. Northrup \& Richard L. Rowan (Eds.), The Negro and employment opportunity: problems and practices (pp. 147-154). Ann Arbor, MI: Burea of Industrial Relations, Graduate School of Business Administration, University of Michigan. 